\title{
Religiões e religiosidades ameríndias: Regimes de saber, diversidade e mediações na experiência religiosa em contextos indígenas
}

\section{A Missão das Irmãzinhas de Jesus de Charles de Foucauld entre os índios Tapirapé}

The Mission of the Little Sisters of Jesus by Charles de Foucauld among the Tapirape Indians

Siloeh Cerqueira Lopes Piermatei ${ }^{1}$

\begin{abstract}
Resumo: O presente artigo versa sobre o novo modelo evangelizador e o paradigma da inculturação que vem transformando odiscurso missionário eclesial e remodelando o olhar da Igreja para as populações ameríndias. Há um esforço no sentido de conhecer e entender a prática e a cultura dos povos indígenas. O respeito ao outro e a hospitalidade são condições sine qua non para que haja o encontro, o embate onde se estabelece a confiança e a parceria. Nesse sentido, tenciona-se analisar a prática missionária das Irmãzinhas de Jesus e sua experiência junto aos índios Tapirapé, com a finalidade de entender se a proposta de inculturação, o carisma da fraternidade e a ação efetiva das Irmãzinhas contribuíram para a impedir o genocídio do povo Apyãwa-Tapirapé.
\end{abstract}

Palavras-chave:Inculturação, hospitalidade, respeito.

Abstract: This article focuses on the new model of evangelization and the paradigm of inculturation that has been transforming the ecclesial missionary discourse and reshaping the Church's perspective on Amerindian populations. There is an effort to know and understand the practice and culture of indigenous peoples. Respect for others and hospitality are prerequisites for a meeting, a conflict in which trust and partnership are established. In this sense, it is intended to analyze the missionary practice of the Little Sisters of Jesus and their experience with the Tapirapé Indians, with the purpose of understanding if the proposal of inculturation, the charism of fraternity and the effective action of the Little Sisters contributed to prevent the genocide of the Apyãwa-Tapirapé people.

Keyword: Inculturation, hospitality, respect.

Nosso jeito de viver o evangelho é entrar na vida do povo e viver como o povo vive. Evangelizamos com o testemunho de vida. Primeiro foi conhecer os Tapirapé, respeitar o seu jeito de ser, não julgar nada. Não sabíamos o que podíamos fazer e o

\footnotetext{
${ }^{1}$ Especialização em Ciência da Religião pela Universidade Federal de Juiz de Fora. Mestranda em Ciência da Religião pela Universidade Federal de Juiz de Fora, área de Concentração - Tradições Religiosas e Perspectivas de Diálogo, sob a orientação da prof ${ }^{\mathrm{a}}$. Doutora Maria Cecília dos Santos Ribeiro Simões, UFJF.
} 
que não podíamos fazer, por isso nosso jeito era aprender, aprender, ouvir e respeitar. (CANUTO, 2018, p.7)

\section{Introdução}

O presente artigo faz parte de minha pesquisa de mestrado, onde procuro analisar a experiência das Irmãzinhas de Jesus de Charles de Foucauld entre os índios ApyãwaTapirapé. Durante muitos anos, tanto a ciência quanto a Igreja evangelizadora tiveram a visão equivocada de que a compreensão do outropoderia ser reduzida à cientifização de seus mitos, ritos e símbolos. Segundo Brandão, “ no momento em que a própria ciência abandona a ambição de reduzir diferenças a uma generalidade, e generalizar a vida social mediante leis e princípios universais de explicação, ela começa a aprender que o próprio compreender é um lento desvelar e uma decifração inesgotável. " (1986, p.12). Para alcançar o outro é fundamental que se faça uma codificação do ponto de vista daquele a quem se quer perceber. Teixeira nos remete à imagem do peregrino que se dispõe a expor-se a novas paisagens, a perigos e incertezas. (2012, p.78) O discurso missionário eclesial e a realidade atual propõem como condição missionária o colocar-se em atitude de cooperação em situações adversas. No entanto, ainda antes de uma revisão missiológica na igreja, as irmãzinhas já atuavam sob esse olhar, que se aproximaria de uma proposta de inculturação e diálogo, praticando exatamente o que pregavam. Nesse sentido pergunta-se: seriam as Irmãzinhas de Jesus de Charles de Foucauld progressistas em seu apostolado? Teria Irmãzinha Madalena, sua fundadora, vislumbrado esse ideal de evangelização no qual o diálogo se faz imperativo? Qual o papel representado por essas missionárias na história dos índios Tapirapé?

\section{O chamado}

A Fraternidade das Irmãzinhas de Jesus foi fundada em 1939, na Argélia, pela Irmãzinha Madalena, que sonhou seguir o exemplo de vida do Beato Charles de Foucauld, cujo lema era gritar o evangelho com a própria vida. Irmãzinha Madalena insistia na ideia de "fermento na massa", que explica sua forma de vida religiosa, não fora do mundo, mas no meio da massa para ser uma só coisa com ela, vivendo uma vida contemplativa consagrada a Deus e aos irmãos e irmãs. Madalena sonhava em abrir uma fraternidade na América Latina. Soube, então, através de frades dominicanos franceses que missionavam em terras do Araguaia, da existência dos Tapirapé, um povo Tupi-Guarani, habitantes da região da Serra 
do Urubu Branco, no Estado do Mato Grosso, à beira do genocídio, com cerca de 50 indivíduos e decidiu que levariam a fraternidade das Irmãzinhas de Jesus até esse grupo.

Em 24 de junho de 1952, Irmãzinha Madalena desembarcou no Brasil em direção à Aldeia Urubu Branco, trazendo três irmãs francesas que aqui permaneceriam, dispostas a partilhar a vida em uma aldeia indígena, apesar de cientes de que enfrentariam muitas dificuldades. (CASALDÁLIGA, 2002, p. 21)Haviam desembarcado no Rio de Janeiro semanas antes de partir para o Mato Grosso. Chegaram discretas, não foram direto para a aldeia Tapirapé, mas ficaram dois meses e meio no colégio das Irmãs Dominicanas em Conceição do Araguaia aprendendo o português de forma acelerada e tudo o que poderia lhes ser útil na prática. (REMY, 2018, p. 31) Começaram a se familiarizar com com os trabalhos manuais, queriam saber sobre o que era permitido e o que não era, aprenderam a conduzir canoa e tantas outras coisas que faziam parte do dia a dia na aldeia, afim de serem sempre fiéis aos ensinamentos da fundadora e viver conforme os princípios idealizados por ela.

O apostolado da Fraternidade fundamenta-se na prática diária da palavra de Deus com os excluídos e marginalizados, partilhando suas vidas, suas histórias, suas dores e esperanças de uma vida digna e humana. (Boletim Verde, p. 12/13) E imbuídas desse espírito, as irmãzinhas vieram para o Brasil. E passaram a viver a vida dos Tapirapé, respeitando suas crenças, seus rituais, mantendo-se observadoras, mas co-participativas. Apesar da dificuldade com a língua, especialmente a língua Tapirapé, abraçaram com aparente excitação essa nova aventura.

\section{Os Apyãwa-Tapirapé}

Os Tapirapé constituem um povo Tupi-Guarani habitante da região da serra do Urubu Branco, no estado do Mato Grosso. Em meados do século XX sofreram intenso declínio populacional devido aos diversos confrontos com os índios Kayapó. Seu território compreendia a margem esquerda do rio Araguaia divididos em 5 aldeias. Um violento surto de malária, gripe e até mesmo simples resfriado causou a morte de grande parte da população da tribo, reduzindo o número de integrantes a menos de 100 no final da década de 1940 .

Quando as Irmãzinhas chegaram, a prioridade era a saúde dos índios. Eles eram muito sensíveis às doenças transmitidas pelos brancos, conforme anotações no diário das Irmãzinhas: “... quase todos os Tapirapé estão doentes com gripe. Alguns bem abatidos pela febre. Não podem caçar, pescar nem mesmo ir à roça buscar alguma coisa para comer. A fome ronda a aldeia e o ambiente fica pesado...”(CASALDÁLIGA, 2002, p. 90).Além disso, 
houve um considerável aumento nos ataques sofridos por eles que, para não serem exterminados, foram protegidos pelos padres dominicanos e por integrantes do $\mathrm{SPI}^{2}$ que montaram um posto de atendimento aos nativos depois de conseguirem persuadi-los a se instalar perto do rio Tapirapé com o rio Araguaia, onde também havia uma aldeia Karajá. (REMY, 2018.p.33)

De acordo com o antropólogo Charles Wagley o povo Tapirapé é marcado por uma história de luta pela posse de suas terras no final da década de 60 e toda a década de 70 . As Irmãzinhas de Jesus asseguraram, por sua ação efetiva, a sobrevivência física dos índios que eram ameaçados pela expansão pecuária que obrigou os Tapirapé a se unirem aos Karajá em defesa de seu território. Foram anos de violência, perseguição política e mortes em toda região do Araguaia. Pe. François Jentel, Dom Pedro Casaldáliga, bispo da Prelazia de São Félix do Araguaia, e as Irmãzinhas de Jesus assistiam os Tapirapé, os defendiam contra os grandes latifundiários e os representavam nas tumultuadas reuniões com os poderosos representantes das Companhias de Desenvolvimento e junto a FUNAI. (WAGLEY, 1988, p.21).

A partir de 1993, com o reconhecimento da $\mathrm{TI}^{3}$ Tapirapé/Karajá, os Tapirapé passam a reivindicar a posse de suas terras na região do Urubu Branco, aonde habitaram até os anos de 1980 e depois passaram a utilizá-la como zona de caça, coleta e práticas religiosas. Em 1994, a presidência da Funai aprovou o relatório produzido por técnicos designados no ano anterior para definir a área da TI Urubu Branco conforme proposta dos Tapirapé. Em outubro de 1996 o Ministro da Justiça, Nelson Jobim, assinou a portaria 599 declarando essa Terra Indígena como sendo de posse permanente dos Tapirapé, a qual foi homologada no mesmo ano.(TORAL, 1997)

Durante todo esse tempo de convivência e amizade, as Irmãzinhas tiveram o cuidado e a preocupação de encorajar a autonomia dos nativos estimulando-os a assumir responsabilidades e iniciativas nas relações com os não indígenas. Elas os acompanhavam e apoiavam, mas eles tomavam as decisões.(REMY, 2018, p. 56)

\footnotetext{
${ }^{2}$ SPI: Serviço de proteção ao Índiofoi criado em 1910 e operou em diferentes formatos até 1967, quando foi substituído pela Fundação Nacional do Índio (Funai), que vigora até os dias de hoje.

${ }^{3}$ Terra Indígena (TI) é uma porção do território nacional, de propriedade da União, habitada por um ou mais povos indígenas, por ele(s) utilizada para suas atividades produtivas, imprescindível à preservação dos recursos ambientais necessários a seu bem-estar e necessária à sua reprodução física e cultural, segundo seus usos, costumes e tradições. Trata-se de um tipo específico de posse, de natureza originária e coletiva, que não se confunde com o conceito civilista de propriedade privada.
} 


\section{A missão}

Num mundo marcado pela injustiça e pela violência, Irmãzinha Madalenaansiava que suas fraternidades surgissem como pequenos oásis onde todos pudessem encontrar a esperança e o conforto. As Irmãzinhas assumem como missão na Igreja levar Jesus para fora de suas próprias fronteiras, alargando sempre o horizonte aos lugares de fraturas humanas de marginalidade e exclusão. Como legado, a fraternidade busca o absoluto de Deus, contemplação no mundo dos pobres num estado de simplicidade, de alegria que consiste na confiança, no abandono nas mãos de Deus. (Boletim Verde, p. 12/13). Nesse contexto, pergunta-se: se a intenção não era evangelizar, qual seria o objetivo da missão enquanto missão?

Quando as Irmãzinhas de Jesus decidiram levar a fraternidade para a aldeia Tapirapé, o objetivo primeiro era fazer-lhes conhecer o seu Deus. Tentaram durante anos, mesmo que de maneira delicada e respeitosa, demonstrar que resistiam a algumas leis dos índios. Irmãzinha Genoveva ${ }^{4}$ escreveu: “... durante os primeiros vinte anos nós tentamos "dizer" nossa fé aos Tapirapé... nós lhes propusemos muitas vezes nossa maneira de reagir a algumas de suas leis, era uma preocupação para nós, mas nunca lhes impusemos nosso modo de crer...”.(REMY, 2018, p. 34) A medida que o tempo passava, foram percebendo que o ritual era a força que os movia e chegaram à conclusão de que os nativos não precisavam ser católicos para viver, e o batismo foi aos poucos sendo abolido e os rituais católicos praticados em discrição.

A proposta da Fraternidade das Irmãzinhas era de seguir os passos do Irmão Charles de Foucauld, gritar o Evangelho aos excluídos e marginalizados simplesmente a partir da convivência, não tentando impor sua religião nem permitindo que os Tapirapé perdessem suas raízes culturais e religiosas. Apesar do batismo imposto aos Tapirapé devido às limitações de certa visão da Igreja na época, a fraternidade assumiu uma nova visão de missão e de diálogo inter-religioso. Paulo Suess diz:

O paradigma da inculturação tem cabeça de Janus. Olhando para trás, e face ao cristianismo colonial, significa uma reparação histórica. Olhando para frente e ao lado, significa uma recuperação da credibilidade e das raízes fundantes do próprio cristianismo e das razões pelas quais o Verbo de Deus se fez carne: diálogo e libertação, reconhecimento na igualdade e shalom na diversidade. Ambos os olhares são precários. A voz de Deus clama sempre por uma escuta melhor e por uma prática mais relevante e radicalmente nova. Atrás do paradigma da "evangelização inculturada" está uma luta histórica, não pelo conceito, mas pela prática de uma

\footnotetext{
${ }^{4}$ Irmãzinha Genoveva foi uma das pioneiras Irmãzinhas francesas que vieram para a missão com os Tapirapé.
} 
evangelização pós-colonial e pelos artigos libertadores da fé, enraizados na vida dos povos. (Mori, 2014)

Na obra Inculturação e Libertação (1986) há algumas questões a respeito do discurso missionário eclesial e a realidade atual e propõe como condição missionária o colocar-se em atitude de co-participação em situações adversas. No entanto, ainda antes de uma revisão missiológica na igreja, as irmãzinhas já atuavam sob esse olhar, que se aproximaria de uma proposta de inculturação e diálogo, superando-a na prática, em muitos aspectos. Suzana Macedo ${ }^{5}$ assinala que:

Dependendo do olhar com o qual se contempla o diálogo inter-religioso, podem resultar atitudes positivas que advém, em grande parte, das experiências missionárias pioneiras vividas entre os povos de tradições religiosas diferentes que são documentadas, narradas e divulgadas, ou atitudes negativas como o etnocentrismo e a intolerância surgidos do desconhecimento e do fechamento dialogal. (MACEDO, 2017, p.261)

Um novo arquétipo indica que o pensamento atual da Igreja é de um novo agir missionário e apresenta questões sobre a missão específica do missionário junto aos povos indígenas e o que significa evangelizar sem manipular ou destruir as culturas dos povos. Conforme Magali Bessone: "o diálogo é, em primeiro lugar, o modo mais natural da palavra quando ela chega ao estado de troca". Ela ainda acrescenta que o diálogo é condição essencial da hospitalidade, pois para que haja o diálogo é imprescindível que se reconheça o outro como um radicalmente distinto, porém, como um igual, pois ele é a exteriorização da hospitalidade uma vez que faz nascer em quem partilha, um modo de pensar. (MONTANDON,2011, p.1267). Sendo assim, teriam as Irmãzinhas de Jesus alcançado seu objetivo de ser fiéis aos ensinamentos de Irmãzinha Madalena e do Irmão Foucauld?

\section{Os Frutos}

Os atuais Tapirapé se autodenominam Apyãwa-Tapirapé, como designam o local dessas aldeias habitadas nas primeiras três décadas do século XX como Yrywo'ywawa, "local onde o Urubu Branco bebe", ou como é conhecida regionalmente, "Serra do Urubu Branco", divididos em 8 aldeias. Caminham rapidamente para atingir o número de 1000 pessoas na

\footnotetext{
${ }^{5}$ Maria Suzana Figueiredo Assis Macedo, Doutora em Ciência da Religião pela UFJF -2017, com a Tese EM TERRA ESTRANGEIRA: hospitalidade e diálogo inter-religioso.
} 
tribo, como no início do século. (REMY, 2018, p. 93). Muitas Irmãzinhas passaram pela aldeia, ficavam por algum tempo e partiam por um motivo ou outro. Mas Irmãzinha Genoveva, Veva como era carinhosamente chamada pelos Apyãwa, foi uma das pioneiras e teve com eles uma experiência que, a princípio seria de poucos meses, mas se prolongou por 65 anos. Oteólogo e escritor Leonardo Boff conta:

\footnotetext{
Naquela ocasião, ao me deparar com os rostos de uma típica índia Tapirapé e da Irmãzinha Genoveva, notei: se esta tivesse tingido de tucum seus cabelos brancos, seria tida por uma perfeita mulher Tapirapé. A convivência deu-lhe a semelhança física porque assumiu a alma da cultura Tapirapé.
}

Irmãzinha Veva morreu em 24 de setembro de 2013 e foi enterrada na aldeia, dentro de sua casa, segundo os costumes Tapirapé. (REMY, 2018, p. 63) As Irmãzinhas de Jesus não estão mais na aldeia. A importância de seu papel para a recuperação desse povo lhes rendeu a alcunha de "parteiras dos Tapirapé", criada pelo teólogo Leonardo Boff, uma vez que, além de cuidarem da saúde do grupo, tiveram papel importante no fortalecimento de sua cultura e na recuperação de seu território. Encorajados e incentivados pelas Irmãzinhas, favoreceram gradualmente a aproximação entre os Apyãwa e seus inimigos de outras etnias, estabelecendo relações anteriormente abaladas, e por consequência, muitos casamentos se realizaram. Além disso, os Tapirapé se uniram a outros povos indígenas e criaram a "Associação dos Povos Tupi do Norte do Brasil”, formada por uma geração entre 30 e 40 anos de idade, que participam de reuniões do CIMI e acompanham atentamente o que acontece no país.(REMY, 2018, p. 59)

\section{Considerações finais}

É imperativo se pensar a missão dentro do contexto atual em que vivemos, superando os traumas que a colonização imprimiu na reflexão teológica. Há vários modelos de evangelização com suas catequeses, sacramentos, instituições de caridade, celebrações, instituições assistenciais, atc. Esses modelos representam poder aliados a outros poderese é imprescindível entender como os povos enquanto "objetos" e "sujeitos" mudam de perfil em decorrência das mudanças nas relações políticas, econômicas, culturais e religiosas. E esse projeto de poder imperou durante muito tempo. No entanto, conforme relata Leonardo Boff, existem figuras de missionários que se sensibilizaram com as diferenças culturais e 
exercitaram um outro caminho para a missão. (BOFF, 2006, p. 13) Neste sentido, as Irmãzinhas de Jesus podem ser um exemplo de hospitalidade e respeito ao outro. Talvez tenham entendido a necessidade de se ter um outro olhar diante de diferentes culturas. Escolheram inculturar, ao invés de impor. Afinal, segundo Boff: "em 50 anos elas não converteram sequer um membro da tribo. Conseguiram muito mais: fizeram-se parteiras de um povo, à luz daquele que entendeu sua missão de trazer vida e vida em abundância" (BOFF, 2006. p.14).

\section{Referências bibliográficas}

BALDUS, Herbert: TAPIRAPÉ - Tribo Tupi no Brasil Central. São Paulo: Companhia Editora Nacional, 1970.

BESSONE, Magali. Do eu aos nós. In: MONTANDON, Alain (Dir.) O livro da hospitalidade: acolhida do estrangeiro na história e nas culturas. São Paulo: SENAC, 2011.

BINET-MONTANDON, Chistiane. Uma construção do vínculo social. In: MONTANDON, Alain (Dir.). O Livro da Hospitalidade: acolhida ao estrangeiro na história e nas culturas. São Paulo: Senac, 2011.p. 1171-1184.

BOLETIM Verde, Jesus Caritas.s.n.t.

BOFF, Leonardo: Hospitalidade, direito e dever de todos. Petrópolis: Vozes, 2005; . Convivência. Respeito e tolerância. Petrópolis: Vozes, 2006; Comer e beber juntos e viver em paz. Petrópolis: Vozes, 2006;

BRANDÃO, Carlos; Inculturação e Libertação. A linha 2 da Comissão Episcopal da CNBB / CIMI. São Paulo: Edições Paulinas, 1986.

IRZ, MADALENA DE JESUS, Jesus é o Deus do impossível. França, Le Livre Ouvert, 1991. IRZ, ANNIE, de Jesus. Irmãzinha Madalena de Jesus, A experiência de Belém, até os confins do mundo, São Paulo: Cidade Nova, 2012.

IRMÃZINHAS DE JESUS, Contemplativas em plena massa humana, disponível em: http://www.hermanitasdejesus.org/brasil/brasil_nuestra historia.htm

KATHRYN, Spink. O chamado do Deserto, Biografia de Irz. Madalena de Jesus, São Paulo: Loyola, 1997.

MACEDO, Maria Suzana F.A.: EM TERRA ESTRANGEIRA: hospitalidade e diálogo interreligioso. Tese, UFJF 2017.

MIRANDA, Mario de F. INCULTURAÇÃO DA FÉ Uma abordagem teológica. São Paulo: Edições Loyola, 2001.

PANIKKAR, Raimon. O Diálogo indispensável, paz entre as religiões, Portugal: Zéfiro, 2007.

PORTAL DAS IRMÃZINHAS DE JESUS, disponível em: http://irmazinhasdejesusbrasil.blogspot.com.br/

REMY, Eliane. PARTEIRAS DE UM POVO 65 anos da presença das Irmãzinhas de Jesus junto ao povo Apuãwa-Tapirapé. Goiânia: Scala Editora, 2018.

SUESS, Paulo. Queimada e semeadura: da conquista espiritual ao descobrimento de uma nova evangelização. Petrópolis, 1988, Vozes.

TEIXEIRA, Faustino. Buscadores Cristãos no Diálogo com o Islã. São Paulo: Paulus, 2014.

TEIXEIRA, Faustino. Buscadores do diálogo itinerários inter-religiosos. São Paulo: Paulus, 2012.

TORAL, André. Instituto Socioambiental / Povos Indígenas no Brasil. Visualizada em 06/07/2018. Disponível em: https://pib.socioambiental.org/pt/Povo:Tapirap\%C3\%A9 


\section{A Linguagem religiosa nas pinturas corporais da etnia Kayapó-Xikrin do Cateté nos rituais de passagem}

The religious language in the corporal paintings of the Kayapo-Xikrin do cateté ethnic group in the rituals of passage

Kátia Moraes de Almeida ${ }^{6}$

Resumo: Este trabalho de conclusão de curso analisa a relação existente entre a linguagem da pintura corporal e os rituais de passagem na etnia Kaiapó-xikrin do Cateté. Estuda a pintura corporal como uma linguagem religiosa na construção do corpo e da pessoa Kayapó-xikrin do Cateté em seu ritual de passagem feminino nhiok, e no ritual de nascimento do filho primogênito, como uma forma de identificação do imaginário simbólico religioso. Desta forma o trabalho pretende relacionar a pintura corporal à construção de identidade social, pessoal e religiosa.

Palavras chave: Linguagem religiosa. Pintura corporal. Rituais de passagem. Kayapó-xikrin do Cateté

Abstract: This articleanalyzes the relationship between the language of body painting and the rituals of passage in the Kaiapó-xikrin of Cateté ethnic group. Itstudies body painting as a religious language in the construction of the body and the Kayapó-xikrin of Cateté person in theirnhiok female ritual of passage, and in the birth ritual of the firstborn son, as a form of identification of the religious symbolic imagery. In this way the work aims to relate body painting to the construction of social, personal and religious identity.

Keywords: Religious language. Body painting. Rituals of passage. Kaiapó-xikrin do Cateté.

\section{A pintura corporal}

O imaginário simbólico é rico em representações. No início da humanidade o homem sentiu a necessidade de se comunicar, desenhou o seu dia a dia, sua vivência, sua sexualidade, seus rituais, sua economia, suas danças, os astros e os seus mistérios. As pinturas rupestres

\footnotetext{
${ }^{6}$ Graduada em Psicologia, CES(JF/MG). Especialista em Gestalt-terapia, e Psicopedagogia. Arte-terapeuta. Título de Especialista Psicologia Clínica. Aluna do Curso de graduação em Ciência da Religião (UFJF). katiaarteterapeuta@hotmail.com
} 
estão registradas nas rochas, nas paredes, em cavernas de diversos sítios arqueológicos espalhados pelo mundo.

A pintura corporal apesar de ser uma atividade executada há milhares de anos, começou a ser valorizada, no contexto ocidental,a partir das décadas de 60 e 70. Através dos movimentos sociais de contracultura, de novas pesquisas sobre o tema e do uso da tatuagem, como uma forma de comunicação, de identificação, e linguagem pictórica.

\begin{abstract}
Apenas recentemente a pintura, a arte gráfica e os ornamentos do corpo passaram a ser considerados como material visual que exprime a concepção tribal de uma pessoa humana, a categorização social e material e outras mensagens referentes à ordem cósmica. Em resumo, manifestações simbólicas e estéticas centrais para a compreensão da vida em sociedade (VIDAL,2000, p.13).
\end{abstract}

As tribos africanas usam a pintura corporal como uma maneira de se comunicar e se identificar, segundo Vidal (2000). Temos também registros de tatuagens e maquiagens usadas em rituais no Egito, três milhões de anos antes de Cristo. A nossa arte contemporânea se expressa também através de tatuagens, as quais observamos tranquilamente nas nossas ruas, principalmente nos corpos dos jovens, nas suas "tribos" como uma linguagem simbólica, representativa. As famosas "Globelezas" exibem o seu corpo pintado durante anos, na época do carnaval, no canal de televisão Rede Globo, em horário nobre. Atualmente vemos fotos de pessoas com roupas, cabelos, e tatuagens coloridas, as quais se referem como uma arte. Assim, podemos perceber que esta forma de expressão é utilizada por diferentes povos, em diferentes épocas da nossa humanidade. O grafismo é um meio de comunicação universal, e o corpo pode ser usadocomo uma tela, representativa desse imaginário simbólico. Temos uma projeção de imagens. A arte corporal usando a pintura, como uma técnica é individual e única de cada etnia ou grupo, e nos revela vários significados e motivos no seu uso.Os povos indígenas usam o grafismo corporal em diversas situações: como uma veste corporal; na vaidade; na estética; na diferenciação das etnias, na identificação; na função social; para mostrar o estado civil; na motivação para o namoro; nas cerimônias religiosas; e em outros motivos. A pintura corporal é uma expressão artística presente,em diversas situações nas sociedades indígenas e moderna. Os indivíduos extraem da natureza a tinta, urucum, jenipapo, babaçu, carvão e outros. Geralmente são utilizadas tintas naturais, de árvores e frutos. Os desenhos, as formas, os rituais, as festas também variam de acordo com a etnia.

A religião é uma linguagem, uma identificação com certos princípios, uma comunicação social com determinadas ideias. Os rituais, mitos, e símbolos, são mediadores do trânsito entre imanente e o transcendente. Uma abertura de sentido para o transcendente. 
Qual é o sentido do rito? De acordo com Croatto (2010, p.329) "o rito é um símbolo em ação". O rito é concreto, cria uma relação com o sagrado, reproduz um ato divino. Coloca a ação sagrada, no tempo e no espaço. O rito estabelece uma materialidade ao símbolo e ao mito, estabelece um aspecto social. O rito é a própria ação sagrada. Através da sua periodicidade, obedece um calendário, recoloca a ação dos deuses, uma "mímesis divina", de acordo com Croatto (2010) regula uma ordenação no tempo e no espaço. Tem o seu caráter fundamental na preservação e harmonia de uma comunidade, para a sua manutenção. $\mathrm{O}$ rito pode perder seu sentido, sua força, com o tempo, e se transformar, ou ser substituído por outro.

O objetivo deste trabalho é investigar a pintura corporal, como uma linguagem, uma comunicação, na etnia Kayapó-xikrin do Cateté. No seu ritual de passagem feminino nhiok, e no ritual de nascimento do primogênito, como uma forma de identificação, do imaginário simbólico religioso. Uma formação de identidade social, pessoal e religiosa.

O trabalho procura também mostrar o valor da pintura corporal indígena da etnia Kayapó-xikrin do Cateté como uma linguagem religiosa, no seu ritual: de passagem feminino, nhiok; e nascimento do primogênito, de acordo com os dados etnográficos coletados pela antropóloga Lux Vidal, bem como relacionar o ritual com a identificação dos papéis sociais; o masculino e o feminino; a passagem de um ciclo; e o isolamento e inclusão social.

A metodologia utilizada foi a revisão bibliográfica de artigos etnográficos. As fontes principais são os estudos da arqueóloga Lux Vidal, especialista na etnia Kayapó-Xikrin do Cateté. Também foram pesquisados autores como Manuela Carneiro da Cunha que organizou a "História dos índios no Brasil" fornecendo importantes dados referentes a história e localização da etnia, além de outros autores apontados ao longo do texto.

\section{Os mitos e os ritos ameríndios.}

Ao longo do processo de colonização os mitos indígenas foram vistos através de uma perspectiva linear, por um olhar ocidental e fora do real sentido da cultura indígena (SILVA, 1994). Com o estudo da linguagem simbólica, mitológica, e a contribuição da semiótica e suas contribuições semânticas para a antropologia, essa atitude muda. A atribuição do mito e do rito é dar sentido, ordenar. Uma maneira do cognitivo se expressar, dizer algo, fazer um discurso, relacionado com o modo de vida de um povo. Os povos contam histórias do início do mundo e outras, através da oralidade, verdades repassadas através das gerações na tentativa de organizar o pensamento humano e compreender o mundo. O mito muitas vezes usa com 
recurso a metáfora, agregando camadas de significação, construindo novos significados no tempo e no espaço, um lugar de reflexão.

As sociedades indígenas também utilizam essa forma de linguagem, com suas questões referentes ao seu modo de vida e contexto, explicando as complexidades do mundo e dando referência de acordo com sua cultura e sociedade. Os seus personagens míticos são humanos, sobre-humanos, monstros divinizados, animais, plantas, aves, peixes e seres. Temos também o totem.

Segundo Lopes da Silva (1994) "as cosmologias são as teorias do mundo". Movimentam-se no tempo e no espaço, sempre dinâmicas. Para os indígenas elas renovam e perpetuam, orientando e dando significado, interpretando acontecimentos e explicando estes como pensamentos sobre o tempo, o espaço e o cosmo em geral. Ajudam a definir a identidade pessoal e grupal, distinta e exclusiva, construída pelo contraste com aquilo que é definido com o outro: a natureza, os mortos, os inimigos, os espíritos.

As narrativas míticas indígenas têm relação com a sua cosmologia, seu universo, sua religiosidade. Articulam a consciência histórica e a consciência mítica (HILL, 1988). Os mitos se referem a vida social e a sua organização. Não são como um espelho. Esta sociedade se torna um objeto de questionamento, e reflexão, serve para reafirma-la (LÉVI-STRAUSS, 1976).

Os mitos se articulam a ritos específicos (VIDAL, 1992). A vinculação entre eles é explícita, usando os cenários, personagens, animais, e a natureza. Um tema é abordado diversamente. Este pode ser narrado, outros uma linguagem. São os temas centrais da vida social ou da cosmologia do grupo (LALLEMAND, 1978). Expressam a realidade e são vivenciados como uma forma de manutenção de valores e significados próprios. Tem uma relação com a construção da pessoa, pois existe uma categoria de pessoa na sociedade indígena, na qual é construída, são exemplos: rituais de passagem de nascimento, fúnebre, e nominação.

Não é um estado simples e uno, um fato primitivo, um dado imediato: a pessoa é mediata, construída e complexa. Não é uma categoria imutável, coeterna ao homem, é uma função que se elabora diversamente através da história e que continua a se elaborar diante de nós (MEYERSON 1973:8).

De acordo com Cunha (2010, p.51), Marcel Mauss é quem relaciona a emergência da pessoa com condições de tempo e espaço, inserindo-a em organizações. 
As relações das pessoas nas sociedades indígenas são elaboradas como um todo, um círculo, onde os indivíduos possuem papéis, não individualizados, mas em relações diretas com a sociedade, funções. Não podemos pensar com a nossa lógica, é um outro ponto de vista. A especificidade não está na alma e sim no corpo, são novos quadros conceituais. Cada grupo vai ter a sua perspectiva ("ponto de vista"), conforme apresento em seguida.

Eduardo Viveiros de Castro (2002) coloca os conceitos de relativismo, perspectivismo e multinaturalismo. A concepção ameríndia tem uma unidade no espírito e uma diversidade dos corpos. Os animais são gente, ou "se vêem como gente", sendo a sua forma animal uma roupapara disfarçar a sua forma humana. Os seres transespecíficos, os xamãs, são dotados de capacidades para ver o que os olhos dos homens não conseguem (um dom revelado em algum momento da vida por um chamado). Essa noção de "roupa" é usada como uma metamorfose dos espíritos, dos mortos, e xamãs, que assumem outras formas animais em um trânsito por mundos invisíveis. O xamã povoa a mitologia indígena amazônica. Ponto de fuga universal do perspectivismo mitológico, meio pré-subjetivo e pré-objetivo. "Os mitos falam como os animais perderam os atributos herdados ou mantidos pelos humanos" (LÉVI-STRAUSS 1985: 14, 1990; BRIGHTMAN1993:40,160). O perspectivismo ameríndio está associado na Amazônia ao valor simbólico da caça (serve como alimento, mas é uma oferenda, um presente da natureza, a qual deve ser respeitada e cuidada), e ao xamanismo (multinaturalismodessubjetivado). Xamanismo é aqui visto como uma arte política, uma capacidade. O objeto é visto em outro prisma, possui uma intencionalidade não material, outra percepção, perde seu caráter de objeto. A verdade está na relação, no diálogo com a natureza, e o ator político dessa relação é o xamã.

Os seres possuem natureza múltipla. O "eu" não tem individualidade, e sim o grupo é o mais importante, na condição de coletividade de um conjunto. Notamos essa dissolução da persona em rituais de passagem com a presença do amigo formal. Ele é o outro, a antítese, o retorno ao caos, "estados liminares" (CUNHA, 2010, p. 54). Ao mesmo tempo que é o inimigo é o amigo, participa, vivencia o ritual, se une no tempo e no espaço, quebrando o ego e se dissolvendo na coletividade. Temos na natureza o exemplo da presença do sol e da lua em alguns rituais, os quais são amigos formais, de um processo dialético. Os rituais de corridas de tora, criação do sol, ritos fúnebres e resguardo de parto com as sequências da lua. Sendo estes últimos, ritos fundamentais de início e fim da vida. Tudo tem a sua lógica. A criação e a morte inseridas no espaço e no tempo através do ritual. A condição de pessoa é vivenciada dentro do grupo, e precisa do mesmo para se individualizar, existir. De acordo 
com Cunha (2010, p.55): "São esses os ritos de separação de indivíduos do seio de suas parentelas que tem a ver com a criação e a destruição de um espaço propriamente pessoal".

\section{Os Kayapó-xikrin do Cateté.}

Escolhi como objeto a representação corporal dos Kayapó-xikrin do Cateté, grupo linguístico Macrojê, no sudoeste do Pará, por sua rica ornamentação do corpo e ritos. A etnia Kayapó, língua Jê, localização central no Brasil, é considerada diversa. Sofreu muitas transformações, e adaptou-se. Temos que analisar seu contexto histórico em um período de quatrocentos anos, segundo Cunha:

O nome Kayapó é de origem tupi significa literalmente como macaco. O nome que os Kayapó dão a si mesmos é Mebengokre, que significa literalmente gente do espaço dentro da(s), ou entre a(s), água(s). (CUNHA, 2006, p.311)

Temos os Kayapó meridionais ao norte de Mato Grosso, e os Kayapó setentrionais na área sudeste do Pará, entre os rios Xingú e Tocantins. Nesta região central do Brasil, temos o mesmo nome a muitos povos diferentes, ou o contrário, sendo difícil catalogar. Temos referências de ataques indígenas ao longo do rio Xingu, por povo Jê, no século XIX, descrito como Kayapó. Etnograficamente falando o francês Coudreau, e o missionário francês frei Gil Vilanova em 1891,1896, e 1897, na região da futura vila de Conceição do Araguaia, com relatos de que os Pau d'arco estavam em quatro aldeias separadas, mais ou menos 1500 índios. Elas tinham uma casa de homens solteiros (COUDREAU,1897:205). Refere-se a mais quatro grupos, Kayapó, no oeste do Araguaia. Tinha uma aldeia menor ao norte, os Xikrin com 500 membros, aliados dos Karajá. A separação dos Xikrin de acordo com Vidal, ocorreu no início do século XVIII, através da avaliação da fonética e de sua organização.

\footnotetext{
Segundo, um mito, os ancestrais dos Jê viviam juntos como um só grupo nessa área até descobrirem uma grande árvore nas margens do Tocantis da qual nasciam espigas de milho. Derrubaram a árvore, obtenho assim o milho como planta de cultivo, mas, à medida que recolhiam as sementes, começaram a falar línguas diferentes, e se separaram nos diversos grupos Jê atuais. (CUNHA,2006, p. 313)
}

A partir do desaparecimento das estruturas das metades, da casa dos homens, do sistema de divisão por idades, e o surgimento da importância mercadológica brasileira, a 
sociedade Kayapó se reorientou, em um novo símbolo de poder. Enfraqueceu a ordem comunitária, fortalecendo a individual, surgiu um núcleo familiar, os bens são consumidos dentro da família. As relações domésticas, a relação hierárquica, genros e sogros também se fortalecem. A idade da casa dos homens não é mais o foco. Isso influencia a idade do casamento, passaram a se casar mais cedo. $\mathrm{Na}$ "casa dos homens" o importante era "reforçar a dominação dos pais sobre seus genros potenciais." (CUNHA, 2006: 336)

O sistema ritualístico também sofre mudanças, antes mediador passa a ser mantenedor. A aproximação da sociedade brasileira é vista como uma ameaça envolvente, capaz de mudar as relações sociais. Os rituais são mais valorizados no sentido de identidade para proteger os arquétipos tribais.

\title{
4. Os rituais dos Kayapó-xikrin do Cateté
}

Nessa etnia a passagem ritual do mundo dos espíritos para a vida terrena, começa no nascimento, é identificada através da pintura corporal aplicada ao corpo, valorizando a beleza, a vaidade, sem perder a função social mágico-religiosa. Essa tarefa da pintura é exclusivamente feminina, elas fazem à sua própria aplicação.

\begin{abstract}
As mulheres sempre apresentam com uma mão (paleta) suja de tinta e a outra branca a que segura. Os motivos são sempre geométricos, obedecendo a linhas retas e quebradas, formando triângulos ou quadrados. Os motivos decorativos das faces e do corpo possuem denominações que se referem ao meio ambiente, como flora e fauna, ou mesmo objetos do cotidiano. Segundo alguns estudiosos, para a sua definição exata seria necessário a identificação dos autores. A pintura corporal nas crianças significa carinho e interesse pela socialização das crianças, elas passam horas pintando seus filhos, é através do corpo do seu filho que elas aprimoram e têm mais liberdade na sua aplicação. Nos adultos a pintura obedece a um padrão mais rígido de acordo com categoria a que pertencem". (VIDAL, 2000, p. 146)
\end{abstract}

Segundo Vidal (2000), as mulheres se pintam entre si, isso acontece a cada oito dias, formando uma sociedade de mulheres divididas em grupos por idades, que podem ser casadas, idosas, solteiras, e jovens. Cada grupo de mulheres tem sua líder. A identificação do grupo é através da pintura facial enquanto a corporal é igual. De acordo com Vidal (2000, p.17) "no contexto tribal, mais que em qualquer outro, a arte funciona como um meio de comunicação. Disso emana a força, a autenticidade e o valor da estética tribal".

A ornamentação dos Kayapó- Xikrin do Catetéé um idioma código, segundo Vidal (2000). Mauss em 1950 já revela que a identificação de valores culturais pode ser revelada 
através da ornamentação do corpo. Lévi-Strauss interpreta as pinturas corporais de mulheres Kadiweu na sua estrutura social, em 1955, identificando um estilo, um símbolo, um sistema. Turner (1969 e 1980) analisa a pintura corporal como uma segunda pele, "socialização" do corpo humano (VIDAL, 2000, p.143).

Os Kayapó- Xikrin do Cateté se comunicam através da sua ornamentação, uma expressão gramatical da sua cosmologia, da sua sociedade, sua relação com a natureza, sua identidade e alteridade. Eles possuem uma grande variedade de motivos gráficos (peixes, animais, aves, e outros símbolos da natureza) para se expressar. O corpo é usado como a expressão da pintura. Uma maneira de se expor; uma "correspondência entre o ético e o estético", uma forma "mágico-religiosa" e cultural, segundo Vidal (2000, p. 144). Estabelece papéis sociais, através dos rituais, expressados com o grafismo corporal.

Nos rituais existem conexões internas, as quais estabelecem um lugar na sociedade. Através da pintura temos uma "encarnação" de um personagem social. A ornamentação corporal é uma projeção, uma maneira de se apresentar para o grupo. Uma forma de se organizar socialmente, uma unificação.

As estampas são compostas por desenhos paralelos, um "desenho-base", seguidos ou não de um motivo decorativo, segundo Vidal (2000, p.146). Os motivos são retirados da natureza, ou de algum objeto de uso regular, utensílio.

A pintura é uma tarefa feminina. A "padronagem" nos adultos é mais rígida. A pintura é uma classificação do indivíduo, identifica este a sua iniciação, estado civil, número de filhos, fim do resguardo, luto, posição guerreira. As mulheres além de se pintarem entre si, e dos seus filhos, também pintam seus maridos, irmãos e pai, sendo estes viúvos. Elas se dividem em grupos por classificação etária, cada um com sua chefe. A pintura é um ato de prazer e está ligada a perfeição. É uma identificação grupal e social.

É usado o urucum, jenipapo misturado com água e carvão. Os instrumentos são feixes de estilete feitos da nervura da folha de babaçu. O ouriço de coco de inajá é usado como um recipiente. São usados também pentes, e carimbos.

A pintura visual corporal, ordena um sistema rígido e estruturado, estabelece um código interno de conjuntos e eventos. Temos dois polos: um de retraimento social, isolamento (com pinturas corporais de tintura de urucum); e outro polo de participação ativa na sociedade, em ações masculinas ou femininas, de acordo com a faixa etária. São usadas estampas de jenipapo. Temos ainda uma fase intermediária, transitória, de acordo com Vidal (2000, p. 158), "em que a natureza e a ordenação das unidades gráficas diferem de acordo com o evento". 


\section{O nascimento do filho primogênito.}

O início do resguardo e o seu fim, do nascimento do filho primogênito, interfere na aldeia por um determinado tempo. Este fato é revelado através de pinturas corporais, e suas sequências pictóricas do nascimento do primogênito de um casal. A criança; os pais; os avôs materno e paterno, os tios maternos (ngêt); avós materna e paterna, e tias paternas (kwatui), também participam do ritual. Cada cor e substância têm suas definições, seus significados, e suas "padronagens". De acordo com Vidal (2000, p.158), "Estabelece-se um quadro, ao mesmo tempo sincrônico e diacrônico do acontecimento pictórico e de seu desenvolvimento que esclarece aspectos cruciais da dinâmica social".

Abaixo, descrevemos a sequência da pintura corporal do pai e da mãe, de acordo Vidal (2000):

Nos sete primeiros dias após o nascimento, o irmão da mãe faz a indumentária do bebê: tipóia e pequena esteira trançadas em folha de buriti. A mãe e o pai, cada um aplica sua camada de tintura de urucum. Essa fase indica uma posição liminar de periferia, e severas restrições alimentares.

Com a queda do cordão umbilical, que acontece no oitavo dia. A mãe aplica uma camada de urucum. O pai tem seus cabelos untados com óleo de babaçu; face enegrecida com carvão e corpo pintado com urucum. O pai reintegra no conselho dos homens, sai da periferia e vai para o centro. É ornamentado por uma amiga formal e levado ao centro da praça por um amigo formal.

No nono dia temos o primeiro banho do bebê; e a perfuração do lábio inferior pelo avô materno. É feito o primeiro desenho da jovem mãe, representando um peixe. É usada a pintura de jenipapo. "Fim das restrições". Reintegração na comunidade. Pintura sempre feita por parentes, mulheres. O pai tem a face e corpo inteiramente enegrecido com carvão.

No décimo dia, a mãe continua na mesma posição, e o pai reafirma o fim do período de restrições. Usa-se como material a pintura de jenipapo, todo negro (me-tuk).

No décimo segundo dia, a mãe é pintada com um desenho feminino indicando o término do período de restrições, com a representação do couro da onça. O pai é pintado com um desenho para homens adultos. Em ambos é usada a pintura com jenipapo. Encerra-se o ritual para o pai.

No décimo sétimo dia a mãe, é pintada com jenipapo, indicando o período de fim das restrições. Diferem apenas no desenho do rosto, feminino. 
Fim do ritual acontece com dois meses, a mãe é pintada com jenipapo, com desenhos femininos. Ela volta definitivamente para a sua participação na vida comunitária.

Os aspectos enfatizados são: a nova família nuclear; a bilateralidade do parentesco e de suas relações rituais; a dicotomia espacial, de um lado a esfera doméstica, domínio feminino, e de outro o centro da praça, domínio masculino, o conselho dos homens; perfuração do lábio inferior, do recém-nascido masculino; uso do disco labial vermelho pelo pai, com o significado de reintegrar o conselho dos homens, sinalizando o "perigo e poder".

Para a mulher o ritual não é tão expressivo quanto o masculino, mas é longo, leva dois meses, se situa na periferia, e ao final ela é aceita como um membro da "sociedade das pintoras", considerada como uma instituição pública feminina de importante valor social para esta etnia.

Os homens são os responsáveis pela formação do feto no útero. A mãe é valorizada somente após o nascimento. Há uma relação com o leite e o sêmen. A pintura da mãe vem justamente mostrar essa relação para a comunidade, dando uma ênfase ao seu papel materno diante de toda a sociedade.

A arte gráfica nesta etnia também usa penas, plumas de aves, palhas, algodão e cera. Rituais de ciclos cósmicos, reiniciados a cada cinco anos. São cinco fases: mekutop são os artefatos plumários; kukrutmenoronu, refere-se as caças (antas); ngroamenoronu relacionado aos vegetais (buriti); ngôreraixi refere-se à pesca; o último é o mekukatuk refere-se a "alma dos mortos", segundo Vidal (2000, p.166).

Temos relatos de pinturas feitas em papel, mas estas são mais simples e não possuem significado ritualístico. São relatadas com um aspecto terapêutico e decorativo.

\section{A nominação feminina.}

No ritual feminino de nominação, nhiok, segundo Vidal (2000) inicia-se um processo de formação de identidade pessoal e social com a pintura corporal das nominadas, com o motivo kueku ã ôk. A estampa dejenipapo aplicada inicialmente no rosto das meninas, com estilete, representa "a socialização" do corpo humano.

$\mathrm{Na}$ parte frontal da cabeça, já raspada, aplica-se um "desenho de linhas pretas de carvão misturado com resina,..., para afastar a alma dos mortos. Elas recebem o nome de suas kwatui(avós ou irmãs do pai), dentro das suas casas" Vidal (2000, p.170). As nominadas ficam na frente das suas casas e imitam beija-flores. Ao lado está sua nominadora e suas amigas formais. 
Aparecem os homens-onças, suas pinturas são realizadas por eles, na casa dos homens. A pintura corporal é feita com carvão tanto no corpo como na face. Temos representações de onças pintadas, parda e preta. Aparecem as mulheres-onças, amigas dos homens-onças, se posicionam na frente dos homens. Aparece o filho da onça. Todos os participantes estão com a pintura mekukatuk, pintura de carvão na testa. A representante mais idosa, nhiok, nome "bonito", também usa a pintura na testa. Elas nominadas, nhiok, são enfeitadas com o pré (cinto), o kadjot-ia-budjá (bandoleira de algodão com três penas de arara vermelha) e um diadema (penas de garça branca e arara preta).

Os homens-onça ostentam capacetes, com um olho ou dois olhos, de cera de abelha. Seus corpos estão recobertos com penas de periquito ou papagaio. Essa passagem representa uma metamorfose da onça em gavião-real. Os pais das nhiok, colocam nelas os seus cocares. Elas estão com seu corpo recoberto de penugens, e na cabeça tem uma penugem de urubu-rei.

Finalizando o ritual, todo o corpo é coberto com carvão pelos pais das meninas nominadas:

O uso de tintura de carvão e de pó azul da casca de ovo de ave de Tinamus, pelos homens, representa um processo de transformação. No ritual de nominação feminina nhiok percebe-se a transformação da onça em gavião, assim como das nominadas em beija-flores, aptas a voar. (VIDAL, 2000, p. 174)

\section{Conclusão}

Os grafismos corporais indígenas são muitas vezes considerados, por um olhar externo, como uma arte, mais são o instrumento para a construção religiosa da identidade. Os rituais e os seus mitos são expressos através das manifestações artísticas corporais, uma forma de linguagem. Os arquétipos coletivos são ritualizados na tela do corpo humano, tatuados, afirmados, identificados, mais que simplesmente uma pintura, são simbolizados no ritual. Uma linguagem dos deuses, expressada na vivência da sua arte, representada com o suor, na pele, o invólucro, o corpo humano. Quando o corpo é a tela, a arte é sentida, no seu contexto maior. O corpo passa a ser a arte, o rito, tudo se mistura, a arte passa a ser o corpo e o rito vivo. O sagrado se manifesta, inexplicável e mágico. A força oculta se revela, se materializa através do ritual.

A linguagem dessa etnia nos revela muitos símbolos visuais, estruturados, expressando uma cosmologia, elaborando um modelo, um código. Usa a ornamentação do corpo e a pintura corporal como uma mensagem para exprimir sua estrutura interna simbólica. O corpo nos revela através das suas pinturas corporais, uma estrutura social organizada, aspectos de 
gênero são observados, os papéis são definidos. $O$ papel da mulher se situa na periferia, possui seu valor social, seu sistema de identificação. Através da sociedade de mulheres pintoras é valorizado. Existe uma liderança feminina, nas casas.

Tanto o ritual do nascimento do filho primogênito, quanto o ritual feminino das nominadas, nos remetem para uma fase, um início, uma passagem de um estado para outro. Situa no tempo e no espaço, reafirma o valor da vida, o sagrado. A pintura corporal ritualística da etnia Kayapós-xikrin dos Cateté, é o veículo para o ritual ser sacramentado aos nossos olhos. Para concretizar, dar materialidade ao rito. No ato de olhar a existência é reafirmada. A pintura corporal é socializada através do ritual. A pintura corporal ritualística é uma linguagem religiosa.

Os dois rituais da etnia Kayapó-Xikrin dos Catetés, são rituais de passagem. O primeiro com início no resguardo, interfere na aldeia, na comunidade. O ritual apresenta uma dinâmica social, onde os indivíduos têm uma relação de parentesco e inclui os amigos formais. Apresenta aproximações e posições de periferia. Associa ao ritual, restrições alimentares. Nessa sociedade temos uma divisão por gêneros, em casas de mulheres, sociedade das mulheres pintoras, e conselhos de homens.

O segundo ritual das meninas nominadas apresenta um momento da participação de toda a comunidade, inclusive das amigas formais. Um processo de transformação da onça em gavião, e das meninas nominadas transformadas em beija-flores, aptas a voar.

Notamos a alteridade, a dialética. A religiosidade é vivida e sentida como um processo de identidade, de definição, uma etapa social, não individual, para a preservação da comunidade. O corpo define o coletivo, constrói, através do ritual. Os seres possuem natureza múltipla. O sagrado é vivificado no corpo. Faz parte dessa construção e manutenção social, o coletivo.

Segundo Hall (2011, p.71) "Todas as identidades estão localizadas no espaço e no tempo simbólicos". Os rituais são os veículos para essas identidades se expressarem simbolicamente através da linguagem artística dessa etnia, reafirmando sua religiosidade. Mantendo assim seus arquétipos e símbolos. Preservando sua cultura, e sua origem.Os rituais religiosos servem como uma referência de identidade, para a manutenção dessa cultura. Uma linguagem religiosa, a qual usa a arte visual como uma técnica expressa no corpo humano. $\mathrm{O}$ corpo no ritual é a representação física, concreta dos ritos, uma tela visível aos nossos olhos através das suas cores, canções, e personificações vivas do ritual no tempo e no espaço. 


\section{Referências bibliográficas}

CARNEIRO DA CUNHA, Manuela. De amigos formais e Companheiros. Escatologia entre os Krahô. In: Cultura com Aspas. São Paulo: Cosac \&Naify, 2010. P. 51-76.

CUNHA, Manuela Carneiro, (Org.). História dos índios no Brasil. São Paulo: Companhia das letras: Secretaria Municipal de Cultura: FAPESP, 1992. p. 311-338.

CROATTO, José Severino. As linguagens da experiência religiosa. Uma Introdução à fenomenologia da religião. São Paulo: Paulinas, 2010. p. 86-352.

HALL, Stuart. A identidade cultural na pós-modernidade. Rio de Janeiro: DP\&A, 2011. p. 71.

LOPES DA SILVA, Aracy. Mitos e cosmologias indígenas no Brasil: breve introdução.

GRUPIONI, L.D.B. Índios no Brasil. Brasília: MEC, 1994. P. 75-82.

MAUSS, Marcel. Esquimo: A Study in Social Morphology. Routledge.

VIDAL, Lux, (Org.). Grafismo IndígenaEstudosdeantropologia

SãoPaulo:Edusp,2000. p. 13-189.

VIVEIROS DE CASTRO, Eduardo. O nativo relativo. MANA 8 (1):113-148, 2002.

VIVEIROS DE CASTRO, Eduardo. Perspectivismo e multinaturalismo na América Indígena. In: A inconstância da Alma Selvagem. São Paulo:Cosac\&Naify, 2002. P. 347-399. 


\title{
Mediação missionária e reconstrução da religião xamânica: estranhamentos e adaptações entre missionários protestantes e os Waiwai na metade do século $\mathrm{XX}$
}

\begin{abstract}
Missionary mediation and reconstruction of the shamanic religion: strangeness and adaptations between Protestant missionaries and the Waiwai in the mid-twentieth century
\end{abstract}

\author{
Alfredo Ferreira de Souza ${ }^{7}$ \\ alfredoferreiradesouza@gmail.com
}

Resumo: O artigo privilegia a implantação da Unevangelized Fields Mission entre os Waiwai a partir de 1949, bem como a construção de Kanashen como centro das estratégias para conversão, verificando como se deu os primeiros contatos, buscando pensar a evangelização, as representações construídas e as demais estratégias produzidas pelos missionários. Analisa o teor da pregação com base no cristianismo e os fatores que levaram a conversão dos Waiwai por intermédio de seu principal xamã, Ewká.

Palavras-chave: missões protestantes do século XX, indígenas da América do Sul, representações missionárias, religião tradicional, religião cristã, catequese, conversão ao cristianismo.

\begin{abstract}
The article emphasizes the implantation of the Unevangelized Fields Mission among the Waiwai from 1949, as well as the construction of Kanashen as the center of the strategies for conversion, verifying how the first contacts were made, trying to think about evangelization, the constructed representations and the other strategies produced by the missionaries. It analyzes the content of preaching based on Christianity and the factors that led to the conversion of the Waiwai through their main shaman, Ewka.

Keywords: protestant missions of the twentieth century, indigenous peoples of South America, missionary representations, traditional religion, christian religion, catechesis, conversion to christianity.
\end{abstract}

\section{A Estratégia Missionária}

Em 1948, os planos para o contato entre a $\mathrm{UFM}^{8}$ e os Waiwai são iniciados após o contato com duração de dez anos entre os Macuxi $^{9}$. O país escolhido foi a Guiana Inglesa ${ }^{10}$. Após a concessão do governo britânico para a expedição, a missão entra em contato com os Waiwai em janeiro de 1949. A escolha da Guiana Inglesa é explicada por Claude Leavitt:

\footnotetext{
${ }^{7}$ Doutor em História Social pela Universidade Federal do Rio de Janeiro, professor na Universidade Federal de Roraima.

${ }^{8}$ Univangelized Fields Mission, missão de origem estadunidense, canadense e alemã.

${ }^{9} \mathrm{O}$ envio de missionários para o Território do Rio Branco fez parte de uma estratégia para manter missionários estadunidenses entre indígenas diante das dificuldades impostas pelo Brasil no período da Segunda Guerra Mundial.

${ }^{10}$ Hoje República Cooperativa da Guiana.
} 
The Brazilian Government has refused us permission. One of our missionaries was killed by Indians over there, and the government has made a lot of difficulties ever since. However, the brother of the missionary who went back on the plane is down there trying to persuade them to change their minds. As soon as we get permission we will move across and establish a new station. We are going to go across ourselves next year and try to locate the best site. And then we plan to bring in a light airplane so that the Indians can be tracked down to their remotest villages in the wilderness. None will be able to remain hidden. (Guppy, 1958, p.21)

Na região do alto Essequibo, os missionários são recepcionados por Ewká, um jovem Yáskomo $^{11}$ e líder local. Ewká, juntamente com outros dois líderes importantes, Mîyîwa e Yakuma, tornou-se o principal informante.

A grande empreitada missionária foi a construção de uma aldeia artificial que levou o nome de Kanashen, que significa Deus deseja você ou Deus te ama, ${ }^{12}$ construída próxima das pequenas aldeias waiwai Yakayaka ${ }^{13}$ Erîpoymo $^{14}$ e Mawika ${ }^{15}$. Este local, além de ser um posto missionário, havia-se tornado também um centro de atração dos Waiwai e de outras etnias da região - Hixkaryana, Tiriyó, Mawayana e Katuena - movidos pelas notícias dos remédios alopáticos utilizados na cura de algumas doenças ou ainda pela disponibilidade de miçangas, facas, machados e outros utensílios por parte da missão. Claude Leavitt explica as intenções com relação à atração:

\begin{abstract}
There are probably another two hundred Indians across the border in Brazil, and it is they in whom we are really interested. The Guiana Wai-Wais will act as seeds, spreading the Word to them - that is why we must make concentrated efforts to get the Brazilian Indians to leave their villages and come and settle over here. We are offering them beads, knives, mirrors - everything they love. We have sent messengers across telling them that they will be much better off here. And some have come. (Guppy, 1958, p.20)
\end{abstract}

Os indígenas passaram a morar em Kanashen ao lado da pista de pouso por designação dos missionários que habitavam na outra extremidade. O projeto de atração foi estratégico e sempre acompanhou a permanência da missão no alto Essequibo e, posteriormente, nos rios Mapuera, Anauá e Jatapu. Os missionários se utilizavam de chamarizes para atrair os Waiwai às suas palafitas de modo que pudessem ouvir as pregações. Além da clínica e da escola de alfabetização, o principal atrativo era o cultivo e a disponibilidade de bananas que eram distribuídas aos que ali chegavam.

\footnotetext{
${ }^{11}$ Termo que na língua waiwai significa xamã.

${ }^{12} \mathrm{O}$ termo é composto por Kaan = Deus; $a$ = tu (pronome pessoal na segunda pessoa do singular); she (ou $\left.x e\right)=$ deseja ou ama (verbo no tempo presente na segunda pessoa do singular).

13 Tradução: "banana".

14 Tradução: "assado velho".

15 Tradução: "remoinho fundo".
} 
A pregação se dava por meio de ilustrações e um proto-catecismo cuja estrutura simples podia ser compreendida pelos indígenas. Tal estruturação ${ }^{16}$, além da cadência fonética, utilizava elementos do cotidiano local - como as árvores, as montanhas, os rios, os animais, as pessoas e até mesmo os espíritos - e o responsável por sua criação e origem. Geralmente, perguntavam quem havia feito ou criado no passado esses elementos materiais ou imateriais, e a resposta sempre era a mesma. Segundo Irene Benson, a estrutura se dava da seguinte forma:

Proto-catecismo

Onoke kaapu nakîhcekňe?

Ahnoro Kaan nîkîhcekňe!

Onoke eepu nakîhcekňe?

Ahnoro Kaan nîkîhcekňe!

Onoke toopu nakîhcekňe?

Ahnoro Kaan nîkîhcekňe!

Onoke comoota nakîhcekňe?

Ahnoro Kaan nîkîhcekňe!

Onoke tooto komo nakîhcekňe?

Ahnoro Kaan nîkîhcekňe!
Tradução:

Quem criou o céu?

Foi Deus quem criou no passado! Quem criou o rio?

Foi Deus quem criou no passado! Quem criou a pedra?

Foi Deus quem criou no passado! Quem criou a mata?

Foi Deus quem criou no passado!

Quem criou as pessoas?

Foi Deus quem criou no passado!

(Benson, 2007, p.1)

O alvo era inserir no sistema de representações dos ouvintes o aparato simbólico relacionado ao "arquétipo" divino distinto e desconectado da cosmogonia vigente. O discurso tratava da origem do Universo, incluindo as representações sobre o imaterial e os meios de compreendê-lo e alcançá-lo. A pregação trazia como lastro a nova afirmação teológica que privilegiava $\operatorname{Kaan}^{17}$, a divindade dos missionários, como a única verdadeira, acessível e criadora de todas as coisas. Tudo se originava nele e toda a criação havia sido feita para ele, incluindo a escatologia cataclísmica que incluía o julgamento final e a punição eterna. Logo, somente ele possuía o meio para restaurar a alma e livrá-la da ignorância promovida pela religião local. Os animais (Hyasîrî) considerados poderosos na vida cotidiana não eram senão simples seres da floresta que nada tinham a ver com a espiritualidade do povo. Toda a religião tradicional era, portanto, antagônica à nova divindade apresentada. O caminho teológico, portanto, foi central para a compreensão da lógica das relações entre os missionários e os Waiwai, uma vez que a teologia serviu para articular as práticas da fé no aprofundamento da própria experiência, antecipando a evangelização e a catequese.

16 Essas práticas missionárias estruturaram-se no modelo dos catecismos menores (aos brutos) por sua simplicidade e laconismo.

${ }^{17}$ Esta foi a pronuncia mais próxima que os Waiwai conseguiram expressar para a palavra God. 
A teologia funcionou, evidentemente, como o discurso normativo da missão ${ }^{18}$. Dela decorreu o caminho moral quando desde o início, os missionários se preocuparam em difundir esta nova moralidade no sistema de representações waiwai. Para alcançarem os objetivos, os tópicos escolhidos foram as do Decálogo. Logo, não bastava apenas fixar a figura do Deus único, Kaan, o conceito pecado, também deveria ser introduzido no perspectivismo uma vez que, de acordo com a visão missionária, relativizava o que era considerado moralmente certo e o que era considerado moralmente errado. Isto se aplicou a um conjunto de práticas locais, e todo o discurso sobre a amoralidade indígena vivida entre os Waiwai justificava, segundo a explicação missionária, tanto a presença e a intervenção da missão próxima às aldeias, como todo o esforço empreendido na conversão daqueles que nelas habitavam.

Mais uma vez pode-se perceber que a base do caminho teológico e do conseqüente caminho moral era o texto das Escrituras. Somente ela, na visão missionária, poderia conter a revelação autoritativa de Kaan com sua moralidade pelo criacionismo e pela moral contida no decálogo. Foi por esse fundamento que os missionários buscaram despertar nos Waiwai o interesse pela leitura e, ao que tudo indica, foi o que aconteceu.

Neste ponto foi que surgiu a ideia de que era necessário saber ler. As aulas de alfabetização eram tão freqüentadas quanto as reuniões de estudo bíblico iniciadas alguns meses após a construção do posto. Inicialmente, alguns Wapixana auxiliaram nas traduções, pregações e aprendizado da língua waiwai. Posteriormente, os próprios missionários se esforçaram por aprender e se comunicar por si só ${ }^{19}$, pois falar na língua nativa era falar ao coração, conforme Robert Hawkins:

Temos que aprender a língua nativa, embora seja muito difícil ao missionário, uns aprendem bem, outros não. A língua é a chave para o coração dos índios e isso é uma certeza. A língua da infância é totalmente coração e emoção. No nosso caso, os Waiwai serviam para ajudar no aprendizado da língua, para isso conversávamos muito. Quando podiam ler, usávamos cartas que falavam das dificuldades e de como Deus as usa para abrir o coração, evitando a murmuração. Tudo isso é muito importante ao missionário. (Hawkins, 2002, p.2)

\footnotetext{
18 Ainda sobre a utilização da teologia no cotidiano da missão, mais uma vez Certeau a coloca como normatização a priori de toda a moral cristã. Conferir Certeau, 1994. p. 241.

${ }^{19}$ Para uma discussão mais aprofundada sobre a importância do aprendizado da língua indígena por parte do missionário protestante no processo de evangelização e catequese, consultar Ferreira de Souza, 2003, p. 83 - 87.
} 


\section{A CONVERSÃo dos WaiWai}

A conversão dos Waiwai decorreu da conversão de seu principal xamã, Ewká. Os missionários desde o início perceberam no jovem líder da aldeia de Yakayaka, localidade que ficava a poucos minutos de Kanashen, a oportunidade de propagar o cristianismo entre os indígenas da região. Ewká tinha por volta de 17 a 18 anos quando a missão contatou os Waiwai pela primeira vez em 1949.

$\mathrm{Na}$ década de 1950, a região ainda era afligida por várias doenças como o sarampo, a gripe, a pneumonia e a tuberculose, que dizimavam aldeias inteiras, como afirma Robert Hawkins:

\footnotetext{
Most of the Waiwais lived in Brazil when we first saw them. Just a few lived in British Guyana. There was another tribe of Indians living in Southern British Guiana up until a plague of measles killed all but six of them in the late 1920's. For some unknown reason some of the Waiwais come to live in place of the destroyed tribe. But when we first saw them there were only about 30 or 40 of them in British Guyana. At that time there may have been about 150 or more of them living in the Upper Mapuera River in Brazil. But they were dying out and occasionally spoke of doing so. (Hawkins, 2007, p. 2)
}

As antigas enfermidades ainda persistiam em toda a região. A rota das contaminações parecia ser do Norte para o Sul, ou seja, da região do lavrado para a cabeceira do rio Mapuera, o mesmo sentido do comércio de bens de consumo trazidos e intermediados pelos Wapixana. Tal comércio era um importante incentivador dos contatos entre os povos, incluindo em sua extremidade os seringueiros, castanheiros, habitantes dos quilombos e povos ribeirinhos (Courdreau, 1903). Logo, tudo indica que esse contato comercial foi o principal responsável pelas contaminações que geravam as fortes epidemias sofridas na região.

Esse ambiente parece ter favorecido as terapias alopáticas, transformando-as em um importante meio para a evangelização em Kanashen. Diante das doenças que flagelavam as aldeias e da ineficácia dos Yaskomos por lidarem com algo desconhecido, os missionários dispunham dos remédios que sanavam os enfermos, na maioria das vezes. Por esse motivo, as incursões clínicas sempre vinham acompanhadas de práticas religiosas, ou seja, para cada remédio prescrito ou para cada injeção aplicada, sempre havia um breve discurso que mencionava o poder e a bondade de Kaan e uma oração em forma de rogo, pedindo para que a divindade ajudasse na cura do enfermo. Os resultados obtidos na aldeia impressionavam até aos que não se alinhavam às exigências ético-morais da missão.

Há, evidentemente, uma adequação das estratégias missionárias (como as relacionadas à saúde) e o credo protestante dos pregadores da UFM. Um exemplo disso é o texto de 
Florence Riedle que trata do controle de uma epidemia de sarampo, expondo uma suposta concepção dos Waiwai alinhada à sua própria cosmovisão do poder divino:

\begin{abstract}
We are thankful that measles epidemic is practically over. Four of the villages had measles, the other five did not, which is a miracle in itself as the people visit around so much. Quite a few years ago the whole Taruma tribe was wiped out with measles and I just didn't know what to expect. The Lord undertook in a most wonderful way and most of the Indians only had a light case and there were no deaths. Even the little babies, about whom I was really concerned, came through line. God is good. The Indians themselves testify to the fact that the Lord protected them Irom death because they belonged to Him. "Look," they said. "All the Taruma tribe died from measles because they couldn't talk to God. (Riedle, 1959, p. 5)
\end{abstract}

No início, Ewka - juntamente com outros Yaskomos da redondeza e algumas mulheres - começou a utilizar os hinos e as orações como reforço aos rituais de cura, conforme revela Irene Benson: "Ewká às vezes ia cantar cânticos dos espíritos (dos índios), às vezes ia cantar os hinos da Igreja. Às vezes ia fazer pajelança, às vezes ia orar. Ele estava misturando os dois" (Queiroz 1999, p. 273). O manejo paralelístico e polissêmico entre as divindades da religião mundial e da religião tradicional foi uma tática waiwai para dar um sentido imediato aos fenômenos que presenciavam nas clínicas e nos tratamentos de saúde, além de outras tecnologias missionárias postas em cena no posto.

Para os Waiwai, a princípio, as características de Kaan não diferenciavam das características dos espíritos, velhos conhecidos nas aldeias. A manipulação multiinterpretativa parecia satisfazer naquele momento crítico vivido por Ewká e a maioria dos Yasacomos ante as epidemias constantes, suscitando um grande interesse. Por outro lado, os resultados surpreendentes dos medicamentos sem os rituais xamânicos por parte dos missionários intrigavam os Waiwai. Os missionários perceberam isso e intensificaram o ensino mostrando que as práticas e os rituais tradicionais eram um engano. Isso permitia com que afirmassem que a melhor escolha era a religião trazida na mensagem das Escrituras. Robert Hawkins esclarece sobre a metodologia utilizada na evangelização e o combate ao temido sincretismo:

Sunday afternoon Bible meetings were held regularly in the living room of one of the missionaries' homes. Attendance in those meetings varied from ten to twenty Waiwais. Bible choruses were written by the missionaries and taught to the Waiwais who seemed glad to learn and sing them. Florine's accordion helped a lot in encouraging the singing. Flannelgraph pictures of Bible stories were used almost every meeting for the first few years. Early in the work the Waiwais were told of Jesus' death for all our sins and of His resurrection. They were told that everyone needed to ask Jesus to come into his heart and make him good. This they started to do after about four or five years. But the witchcraft of the witch doctors continued also even after they asked Jesus into their hearts. We told them that the spirits called by the pajés were of Satan and they must be willing to stop all witchcraft for Jesus 
to come into their hearts. This came as a shock to the main pajé of the tribe. He felt he could not give up his witchcraft and so he did both over sick people for a whole, first putting little stone with spirits on them in his mouth, then blowing tobacco smoke over the sick person for one, two or more hours and calling on various spirits loudly. Then He would take the rocks out of his mouth and put away the tobacco and bow and pray to Jesus also to make the person well. But finally he realized the spirits were not happy with this situation and they were not helping him as they did before. So finally he gave up his charms much to the consternation of his wife and the rest of the tribe. (Hawkins, 2007, p. 2)

É nesse contexto que Ewká se converte ao cristianismo após não mais conseguir desempenhar sua função xamânica de curar as novas moléstias e, consequentemente, de preservar o bem-estar social entre os moradores da aldeia ${ }^{20}$. Os doentes que o procuravam eram encaminhados à enfermaria sob a alegação de que a "magia" missionária seria mais forte. A análise de Ruben Caixeta de Queiroz esclarece mais ainda:

\begin{abstract}
Soubemos que um surto de epidemia alastrou-se entre os índios na época em que a missão os encontrou. Os rituais de cura tradicionalmente realizados não surtiam efeito no combate às doenças trazidas pelos brancos (...). As mortes que aconteciam em grande quantidade eram um sinal de que o diálogo entre os Yaskomo e os seus espíritos tinham sido de certa forma interrompido; o xamã já não mais conseguia desempenhar o seu fundamental papel na sociedade waiwai: dialogar com os seres sobrenaturais, prever os fenômenos físicos, garantir a ordem e o bom funcionamento do mundo social e, acima de tudo, garantir a continuidade da vida. As epidemias estavam provocando uma profunda confusão na ordem social e simbólica waiwai. Neste momento, os missionários apresentaram uma nova "ordem espiritual" - o cristianismo. (Queiroz, 1999, p. 275)
\end{abstract}

Ewká parece ter vivenciado um grande dilema diante das suas tentativas frustradas em curar os enfermos que moravam em sua aldeia e arredores. $\mathrm{O}$ cristianismo parecia ao yaskomo uma possibilidade de reorganizar sua posição na rede social em que vivia. Foi a utilização de uma tática onde o resultado poderia ser a reconstrução do seu status como cristão ou a sua morte como yaskomo frustrado. Esse dilema é apresentado por Milton César ao dizer que: "Os espíritos sempre trouxeram conflitos a Elká. Nos casos de cura malsucedidos, o jovem pajé buscava ansiosamente saber por que o espírito não o atendera. ” (Cesar, 2003, p. 9). Tal avaliação pode ser percebida na frase de Ewká, dirigida ao seu irmão Yakuta no momento da opção pela nova religião: "Eu vou aceitar Jesus. Vocês esperam um ano, se eu não morrer nem acontecer nada, vocês também aceitam” (Sabatini, 1998, p. 185).

A conversão de Ewká aconteceu na primeira metade do ano de 1954. Para os missionários foi um grande trunfo ter um Yaskomo tão importante convertido ao cristianismo,

\footnotetext{
${ }^{20} \mathrm{O}$ trabalho realizado pelo yaskomo envolvia uma série de atividades que lhe atribuíam o status de líder na aldeia. O labor envolvia o combate às doenças, orientação ao plantio e à caça, principalmente dos poňikos, interpretação dos sonhos, sonhar ou ter visões reveladoras, coordenar as três principais festas: yamo, shodewika e komo, além de conceder os nomes secretos aos bebês nascidos na aldeia.
} 
além de novamente reforçarem a imagem de homem bom e desejoso de conversão, conforme Robert Hawkins comenta:

Elka realmente mostrou fé em Cristo, o primeiro dentre os Uaiuais. Ele regularmente assistia aos cultos em nossa casa nos domingos à tarde quando muito poucos estavam assistindo. Ele sempre quis ser um homem bom. Assim, foi um dos primeiros que aceitaram Jesus. (Hawkins, 2002, p. 1)

Para o jovem líder, a nova escolha ser-lhe-ia útil, mesmo acreditando que poderia morrer pela mão dos espíritos, pois de acordo com o sistema de representação Waiwai, a conversão trazia sérios riscos à sua integridade física.

Ewká já sabia ler e escrever, além de ser o principal informante para as traduções do material religioso e do material usado nas aulas de alfabetização. Ele seria utilizado a partir de então como instrumento de propagação do Evangelho e para a conversão de outros nas aldeias próximas e distantes. Para isso, a primeira providência tomada foi a de demonstrar a toda aldeia que Ewká havia abandonado o xamanismo em nome da nova religião adotada. A missão decidiu promover uma grande festa para a declaração pública do líder. Eles sabiam que os Waiwai lançavam mão de festas em momentos importantes, sempre contendo muita carne de caça moqueada ${ }^{21}$, cuure $^{22}$, kurayi $^{23}$, lutas corporais e uma dança ritualística chamada shoriwiko ${ }^{24}$, quando os homens se cobriam de folhas e penas.

A festa passaria a ser diferente: seria oferecida garapa não fermentada em lugar do kurayi, haveria competições como cabo-de-guerra, corridas, flecha ao alvo, salto em altura e distância, com o objetivo de substituir a tão condenada shoriwiko. No auge, Ewká viria acompanhado de Claude Leavitt para, em público, se desfazer dos seus apetrechos mágicos e renegar os rituais e os espíritos, agora identificados como Satanás.

Tudo aconteceu conforme o planejado. Por recomendação dos missionários, praticamente todas as aldeias conhecidas foram convidadas pelo jovem converso com antecedência, desde o Essequibo até o distante Mapuera ${ }^{25}$. Centenas de pessoas estavam presentes. Após o tempo de atividades e competições, Claude Leavitt as chamou para que viessem ao pátio da missão para verem o testemunho tão esperado. Em meio às acusações de

\footnotetext{
${ }^{21}$ Processo singular utilizado para defumar a carne e preservá-la da putrefação.

${ }^{22}$ Um tipo de beiju flexível muito apreciado pelos Waiwai.

${ }^{23}$ Bebida fermentada de mandioca feita a partir da mastigação.

24 Ritual antigo extremamente importante para a religião Waiwai e que foi duramente combatida pelos missionários.

${ }^{25}$ Os convites eram enviados às outras aldeias pelo líder local. Tratava-se do shimshim, um barbante feito com fibras de curauá, que continha o número de dias em forma de nós que eram desfeitos diariamente até a data determinada.
} 
Ahmîry, sua esposa, que dizia: “...nossos filhos vão morrer e você vai ser culpado” (Queiroz, 1999, p. 274), Ewká saiu da mîimo ${ }^{26}$ para se colocar ao lado do missionário e, silenciosamente, entregar-lhe diante da plateia a pokara, o pequeno cesto xamânico que continha com os objetos sagrados. Ao receber a pokara, Claude Leavitt iniciou um discurso recomendando que ninguém mais deveria procurar Ewká para práticas xamânicas, pois agora ele se tornara um cristão protestante. O que ele poderia fazer agora era apenas rogar a Kaan pelas pessoas enfermas. Em seguida, fez uma oração e guardou a pokara para usar como comprovação da conversão do Yaskomo, nos EUA, quando fosse fazer a divulgação do trabalho feito em Kanashen. Embora Leavitt tenha sido o articulador do ato público, Robert Hawkins parece ter sido o primeiro a incentivar o abandono dos utensílios ligados à antiga religião, conforme ele mesmo afirma:

Eu disse a Elka: "Meu irmão, é muito bom que você já tenha recebido Jesus como seu salvador. Mas agora você deve jogar no rio todas as coisas mágicas e nunca mais falar com os espíritos chamando-os para fazer curas, só deve falar com Cristo.” Mas parece que ele continuou a invocar Jesus e os espíritos sobre os doentes por um ano. Finalmente, ele ganhou a vitória em seu coração e deu as coisas para Cláudio. (Hawkins, 2002, p. 1)

Este ato público promovido pelos missionários tinha dois objetivos. $\mathrm{O}$ primeiro era confrontar a religião tradicional diante do abandono de um conceituado Yaskomo em prol do cristianismo. O segundo era evidenciar a superioridade do poder de Kaan sobre as entidades veneradas, capaz de proteger o recém-convertido da morte certa. Os missionários apostaram tudo nisso, esperando que outras pessoas viessem a se converter posteriormente. Havia agora a intenção de intensificar ainda mais o contraste iniciado na pregação e no uso dos remédios alopáticos.

\footnotetext{
${ }^{26}$ Termo oriundo da raiz mîn que significa "casa comunal", uma construção central situada próxima a um rio ou igarapé com acesso fácil aos principais rios. Com espaço suficiente para abrigar todas as famílias da aldeia, sua forma circular possuía um diâmetro com medida suficiente à necessidade de todas as famílias, que variava de dez a vinte metros. A estrutura era sustentada pelo mastro principal coberta com folhas de palmeira, tendo ao redor a parede sem janelas, feita de estacas ou do mesmo material da cobertura (nesse caso era uma extensão do telhado). A altura dessa parede variava de acordo com o diâmetro, podendo ser de meio a um metro e meio. O diâmetro também determinava a quantidade de portas que podia ser uma ou duas, sempre em posição da nascente ao poente para aproveitamento da luz solar.
} 


\section{Considerações Finais}

A identificação da luz como revelação da verdade única, a cristã, expressa a tentativa de anular a polissemia que outrora fazia parte do discurso e das práticas de Ewká identificada, por sua vez, às trevas da ignorância, segundo a teologia missionária. $\mathrm{O}$ afastamento das antigas representações e a substituição por outras novas eram estratégias prioritárias para que a cosmovisão cristã reordenasse o sistema de representação dos Waiwai. Ciisusu Kraysutu ${ }^{27}$ nada tinha a ver com os espíritos, logo as homologias tradicionais waiwai soavam como pilhérias que deveriam desaparecer sob uma nova escatologia e uma nova consciência da soberania unilateral da divindade cristã, Kaan e Ciisusu Kraysutu, como totalmente bondade, verdade e justiça. Já os espíritos - associados vitalmente a Satanás - eram totalmente maus, falaciosos e injustos.

É importante salientar que a vinda da UFM aos Waiwai na Guiana Inglesa não aconteceu apenas como estratégia de evangelização indígena na época em que o governo brasileiro, motivado pelos acontecimentos da Segunda Guerra Mundial, havia vetado as missões Kayapó e Guajajara (antigos locais desta missão). A principal motivação em catequizar essas aldeias setentrionais foi a implantação do protestantismo numa área fortemente demarcada pelo catolicismo romano.

O desmembramento da Unevangelized Fields Mission em Belém, foi uma importante estratégia que ultrapassou a simples intenção de constituir uma liderança local. Posicionar o centro das discussões e projetos evangelísticos na fronteira entre o Brasil e a Guiana Inglesa subsidiou o plano de estabelecer o maior número possível de postos missionários entre os índios residentes no lavrado (Macuxi e Wapixana), alto Essequibo (Waiwai), alto Uraricoera, Mucajaí e Parima (Yanomami), além de manter uma comunidade em Georgetown. A maioria da selva amazônica, contida nos respectivos países, era o alvo principal.

Muitos fatores contribuíram para que fosse efetivado este projeto, como a grande disposição de voluntários nos Estados Unidos e a ajuda recebida da FAB. Esta, sem dúvida nenhuma, foi essencial na proteção contra as muitas denúncias e embargos promovidos pelo governo local e o $\mathrm{SPI}^{28}$. Estar "sob as asas da Força Aérea" significou a proteção e a doação de equipamentos necessários para a construção das pistas de pouso, rádios para comunicação e a permanência dos missionários entre os Yanomami $^{29}$. Foi neste contexto que as inúmeras expedições ocorreram como resposta inicial às estratégias elaboradas. $\mathrm{O}$ objetivo era o estabelecimento em aldeias que pudessem servir como centros de expansão do evangelho a outras comunidades próximas por meio de visitas ou atraindo os índios ao posto missionário. Com a parceria da FAB, as ações aplicadas às localidades onde

\footnotetext{
${ }^{27}$ Forma waiwai de se escrever Jesus Cristo.

${ }^{28}$ Como foi tratado neste trabalho, a mudança do nome da missão, de Unevangelized Fields Mission - British Guiana Branch for Indian Work para Cruzada de Evangelização Mundial - Secção Riobranquense foi estratégica, criando, inclusive, o cargo simulado de presidente a ser preenchido por brasileiros.

${ }^{29}$ A FAB também auxiliou na remoção dos Waiwai da região sul da Guiana Inglesa para o noroeste do estado do Pará, no rio Mapuera.
} 
deveriam ser construídos os postos passaram a acompanhar o projeto militar, cujo objetivo era "nacionalizar" as fronteiras entre o Brasil e os países limítrofes. Neste aspecto, os missionários acreditavam ter logrado êxito, uma vez que a implantação desses postos aconteceu conforme o projeto previamente elaborado e as campanhas expedicionárias. (Ferreira de Souza, 2003, p. 152 - 153)

O desejo em contatar os Waiwai se deu, segundo os missionários, pela atração que sentiram pelo povo isolado até então, sem qualquer conhecimento sobre o cristianismo. Pelo menos foi o que revelaram as cartas e os relatórios dos pioneiros.

Na região do alto Essequibo não havia influência do credo romano. Em contrapartida, havia os hábitos convencionalmente chamados de religião tradicional pelo imaginário ocidental. Tal representação incluía os espíritos malignos aprisionadores dos nativos e causadores do medo e dos pecados. De longe, essa foi a maior justificativa utilizada para as campanhas e as intervenções em nome do Evangelho. O desejo de vê-los convertidos e liberados de Kworokyam foi o carro chefe dessas campanhas. É importante salientar que a conversão deveria acontecer mediante o contato com as Escrituras e a obediência à fé apresentada.

Sem dúvida, o yaskomo Ewká foi vital a todo o processo. A aproximação e o investimento por parte dos missionários resultaram na sua conversão e abandono do xamanismo. Esse abandono foi representado em ato público com a entrega da pokara $\left(\right.$ símbolo de Kworokyam $^{30}$ ). Seus gestos influenciaram as transformações decorrentes; suas pregações promoveram várias conversões; seu trabalho de alfabetização letrou muitos dos que viviam ao seu redor. Em suma, Ewká era para a missão um converso a ser imitado. Claro que em meio a tudo havia o ponto áureo: a catequese e a submissão ao texto das Escrituras.

Os contrastes vivenciados e as constantes pregações e ensinos transformaram os que se sentiam desejosos em "fazer o papel falar", "mágica" inicial que se tornou corriqueira na missão e aldeias próximas. Ler e escrever tipificava um status compatível com a posição de um cristão. Afinal de contas, segundo a missão, as letras e sua interpretação eram uma bênção divina, uma graça comum, "um dos dons singulares que os homens da parte de cá receberam de Deus" (Certeau, 2002, p. 216). Esta estratégia pode ser resumida pela declaração de David Crompton:

(1) contatar os índios, fazer um contato; (2) aprender a língua; (3) reduzir esta língua à escrita (fazer um trabalho lingüístico em avaliar a língua e fazer um sistema de escrita); (4) ensinar os índios a ler; (5) traduzir a Palavra de Deus e, (6) entregar o trabalho para eles continuarem. O que está implícito nisto é a idéia de que, uma vez que se aprende a língua e começa explicar o Evangelho, as pessoas vão, obviamente, se alegrar com esta mensagem e se converter. (...) uma vez que aprendem a ler, eles

\footnotetext{
${ }^{30}$ Entidade temida pelos Waiwai.
} 
podem se alimentar espiritualmente da Palavra de Deus que está sendo traduzida. Eles têm tudo que precisam e nós vencemos aquelas barreiras e entregamos a eles a Palavra de Deus na própria língua. E eles têm, então, a responsabilidade, perante Deus, de continuar com isto. Basicamente esta é a estratégia. (Crompton, 2003, p. 13)

Esse foi o ponto para o deslocamento do perspectivismo à lógica ocidental. Kaan fora apresentado, acima de tudo, como o criador independente e possuidor de um ponto de vista global, determinante e único. Este, por sua vez, foi o início para que os vários pontos de vista, fulcro do perspectivismo, se volatilizassem, dando lugar à noção de realidade absoluta. Outro aspecto importante foi a derrocada do corpo, pois Kaan era apenas espírito. Também era onipresente e onisciente, ou seja, sempre estava presente em todo lugar e a todos contemplava. Se o corpo era a sede do ponto de vista específico, dando aos objetos uma determinação, logo a noção de alguém com um ponto de vista generalizado só fazia sentido em alguém que era totalmente espírito.

Essas modalidades proporcionaram ao imaginário local o dualismo preponderante da sociedade ocidental: aquilo que identifica e aquilo que diferencia (identidade e alteridade). $\mathrm{Ou}$ alguém era salvo ou era perdido; ou alguém era convertido ou era ímpio. A grande diferença tornou-se externa em conceitos que oscilavam entre letrado e iletrado, crente ou descrente, Waiwai ou branco, Kaan ou Mawaly, Ciisusu ou Kworokyan etc.

Detalhes à parte, o que chama a atenção são os números referentes ao processo de conversão como resultado das estratégias iniciais, demonstrando o impacto ocorrido nesse encontro. Mesmo com a posterior ausência da missão nas aldeias por anos a fio, até décadas, os Waiwai permaneceram na fé cristã sob a liderança nativa. Eles mesmos se definem como uma nação protestante que rechaça com veemência qualquer resquício da antiga religião. Todas as aldeias, sem exceção, possuem uma igreja onde os cultos são realizados com frequência, incluindo as únicas festas anuais: a páscoa e o natal. Esse foi o resultado advindo da conversão, um cotidiano influenciado pela ordem das manifestações habituais por meio das manifestações do corpo e dos movimentos regido pelas Escrituras.

\section{Referências bibliográficas:}

\section{Entrevistas:}

BENSON, Irene. Transcrição da entrevista feita ao autor. Boa Vista, 14 a 16 de abril de 2007, p. 1 ,

CESAR, Milton. Transcrição da entrevista feita ao autor. Boa Vista, 02 a 07 de junho 2003. FOSTER, Patrick. Transcrição da entrevista feita ao autor. Boa Vista, 1 de janeiro de 2007. 
HAWKINS, Robert. Transcrição da entrevista feita ao autor. Boa Vista, 17 e 18 de setembro de 2002.

\section{Autores consultados:}

CERTEAU, M. de A Escrita da História. 2. ed. Rio de Janeiro: Forense, 2002.

CERTEAU, M. A Invenção do Cotidiano - 1. Artes de Fazer. 7. ed. Petrópolis: Vozes, 1994. COURDREAU. Olga. Voyage a la Mapuera - 21 de avril - 24 decembre 1901. Paris: Lahure Imprimeur, 1903.

DOWDY, Homer. Christ's witchdoctor. New York: Harper \& Row, 1963.

FERREIRA DE SOUZA, Alfredo. O resgate das almas: a missão protestante entre os Yanomami no Território Federal do Rio Branco (1956 - 1963). 2003. 174 f. Dissertação (Mestrado em História Social) - Universidade Federal do Rio de Janeiro, Rio de Janeiro, 2003.

GOODY, Jack. A lógica da escrita e a organização da sociedade. Lisboa, Edições 70: 1987.

GOPPY, Nicholas. Wai-Wai: through the forests north of the Amazon. Londres: John Murray, 1958.

HAWKINS, Robert. [Carta]. 5 de setembro de 2007, Dallas [para] Patrick Foster, Tampa.

LEAVITT, Claude, LEAVITT, Barbara. "From darkness to light". In: Light and Life, Bala Cynwyd e Toronto, v. 20, n. 2, p. 8, abr./jun. 1958.

PUDNEY. Edwin. "General requirements for missionary service". In: Light and Life, Bala Cynwyd e Toronto, v. 20, n. 3, p. 9 - 10, jul./set. 1958.

QUEIROZ, Ruben Caixeta de. "A saga de Ewká: epidemias e evangelização entre os Waiwai". In WRIGHT, Robin. Transformando os deuses. Campinas: 1999.

RIEDLE, Florence. They couldn't talk to God. In: Light and Life, Bala Cynwyd e Toronto, v. 21, n. 3, p. 5, jul./set. 1959.

WAIWAI, Yakuta. Entrevista concedida no dia 10 de fevereiro de 1996 e publicada por SABATINI, S. Massacre. São Paulo: Loyola, 1998. 


\title{
Santidade de Jaguaribe: assimilação e incorporação das práticas católicas no século XVI.
}

\author{
Holiness of Jaguaripe: assimilation and incorporation \\ of Catholic practices in the sixteenth century.
}

\author{
Willian Dias da Silva ${ }^{31}$ \\ wlwl@ig.com.br
}

\begin{abstract}
Resumo: Este artigo busca traçar uma reflexão acerca dos aspectos sincréticos que passaram a integrar o universo indígena, em detrimento do processo de catequização jesuítica. Desta forma, através da assimilação e incorporação das práticas católicas impostas, a cultura indígena foi a primeira a compor o que se denomina como a "Matriz Religiosa Brasileira". A constituição desta matriz no Brasil, cuja gênese se encontra na dominação colonial empreendida por intermédio da Igreja Católica, tem como principal consequência o sincretismo religioso, que caracteriza fortemente a realidade identitária do movimento denominado de "Santidade de Jaguaripe" por volta de 1580 sob a liderança do índio batizado pelos jesuítas de Antônio. O método catequético utilizado pelos jesuítas apresentou um resultado não planejado: os índios assimilaram e incorporaram as práticas católicas, fazendo uma interpretação própria desta catequese convertendo-a a sua cultura e aos seus deuses produzindo então uma um novo sistema de crença com aspectos múltiplos.
\end{abstract}

Palavras-Chave: Assimilação; Jesuítas; Jaguaripe; Santidade; Sincretismo.

Abstract: This article seeks to reflect on the syncretic aspects that have come to integrate the indigenous universe, to the detriment of the process of Jesuit catechesis. Thus, through the assimilation and incorporation of Catholic practices imposed, the indigenous culture was the first to compose what is known as the "Brazilian Religious Matrix". The constitution of this matrix in Brazil, whose genesis lies in the colonial domination undertaken through the Catholic Church, has as its main consequence the religious syncretism, which strongly characterizes the identity of the movement known as the "Holiness of Jaguaripe" around 1580 under leadership of the Indian baptized by the Jesuits of Antônio. The catechetical method used by the Jesuits presented an unplanned result: the Indians assimilated and incorporated Catholic practices, making a proper interpretation of this catechesis converting it to its culture and to its gods, producing a new belief system with multiple aspects.

Keywords: Assimilation; Jesuits; Jaguaripe; Holiness; Syncretism.

\section{Introdução}

A análise da Santidade de Jaguaripe enquanto um agente essencial na assimilação e incorporação das práticas católicas no século XVI considerou os trânsitos culturais percorridos pelos distintos indivíduos no tempo e no espaço de um continente a outro, buscando perceber como se encontraram e como estas relações se estruturaram, visto que

\footnotetext{
${ }^{31}$ Bacharel em Ciências Humanas pela Universidade Federal de Juiz de Fora - UFJF. Este artigo é baseado na Tese de Conclusão de Curso apresentado ao Bacharelado Interdisciplinar em Ciências Humanas como requisito parcial para obtenção do grau e que teve como orientadora a Prof. Dra. Dra. Maria Cecília Ribeiro Simões Rodrigues.
} 
longe das visões dualistas que costumaram opor o Ocidente aos outros, colonizadores e índios, vencidos e vencedores, as fontes nos revelaram paisagens misturadas que produziram um sincretismo religioso. O movimento ficou conhecido através de registros do século XVI, pelos documentos oficiais do governo português, pelas cartas jesuíticas, pelas dezenas de processos e missivas de denúncias nos arquivos do Tribunal do Santo Ofício, onde se encontrou a maior parte dos dados acerca desta Santidade. Mesmo com o seu fim em 1595 e as posteriores sentenças atribuídas a alguns de seus integrantes pelo Tribunal do Santo Ofício, a "Santidade de Jaguaripe" afirmava-se também como uma forma expressiva de resistência a qual os índios recorreram, no sentido de lidar com o domínio dos colonizadores portugueses, atribuindo novos significados aos costumes e práticas tanto no contexto religioso cristão quanto do indígena.

Este "catolicismo a maneira indígena" expressado pelo movimento, trouxe a tona a possibilidade de trabalhar tal temática através de uma abordagem histórica e também interdisciplinar, uma vez que a documentação produzida na gênese do Brasil colonial, especialmente as fontes jesuíticas mostraram a capacidade de mobilização indígena e a complexidade existente no âmbito da sociedade colonial, onde a convivência e assimilação cultural e religiosa faziam-se profundamente presente.

Desta forma, o objetivo geral deste estudo pretendeu tornar evidente a participação do movimento denominado "Santidade de Jaguaripe" no processo de surgimento do Sincretismo Religioso no início do Brasil colônia analisando as suas relações mútuas que produziram certa estrutura religiosa marcada pela reapropriação mútua e porosa que articulou religiosidades diferentes. Neste âmbito o artigo tencionou abordar essa temática indígena no processo de formação da "Matriz Religiosa Brasileira" considerando as fontes da gênese colonial brasileira e de autores que já referenciaram este tema.

Buscamos compreender ainda o complexo universo das relações e das fronteiras sociocultural e religiosa na conjuntura da formação desta matriz religiosa ocorrida na Sociedade Colonial do sul da Bahia, dissertando sobre os atores que compuseram e contribuíram para a formação inicial deste sincretismo religioso no Brasil: os Jesuítas da Companhia de Jesus, que se tornava "a coluna dorsal do poder institucional na colônia" junto com os próprios colonizadores portugueses e os indígenas Tupinambá. 


\section{1- Histórico e contextualização da companhia de Jesus}

No contexto do século XVI, marcado pelo surgimento dos movimentos protestantes e da Contrarreforma, a Companhia de Jesus ou Societas Iesu era fundada em 1534, na cidade de Paris, por Santo Inácio de Loyola e mais seis amigos tendo como objetivo a educação e a missão pela fé católica. Precisamente em 27 de setembro de 1540, a Companhia de Jesus era reconhecida pelo Papa Paulo III, por intermédio da bula Regimini militantis Ecclesiae ${ }^{32}$. Assim a Ordem religiosa consolidava-se enquanto um instrumento missionário e doutrinário da Igreja Católica. (VAINFAS; SOUZA, 1995). Além de realizar missões na Europa e nos territórios sob o domínio do cristianismo, criavam escolas, administravam e mantinham universidades. Neste mesmo ano de 1540, os Jesuítas chegavam a Portugal, por convite do Rei, Dom João III, que pretendia catequizar a Índia. O soberano português, conhecido pelo interesse em proteger e expandir o reino português era grande entusiasta pela unificação da fé católica. Foi ele que conseguiu em 1536, autorização do Papa Paulo, através da bula Cum ad nihil magis ${ }^{33}$ para criação do Tribunal da Inquisição do Santo ofício no reinado lusitano. "Sua política se fundamentava em restaurar as letras e ciências, promovendo assim a cultura portuguesa." (RODRIGUES, 1931 A).

\section{1- A missão jesuítica entre os índios no Brasil}

Após alguns anos de serviço em Portugal, a Ordem expandia-se nas Américas, visto que os jesuítas acreditavam que somente neste "Novo Mundo" poderiam realizar efetivamente sua missão de salvação e evangelização. Para os europeus do século XVI, os nativos americanos eram idênticos "aos caçadores e pescadores recoletores da idade da pedra". Eram considerados povos selvagens e exóticos, mas ao mesmo tempo a qualidade deste povo era destacada através da, "inocência da nudez, da generosidade, da indiferença pela posse de bens materiais e até mesmo pelo sentido de limpeza." $\mathrm{Na}$ esfera natural os indígenas eram tidos como excêntricos, porém no mundo temporal a finalidade era os de lhes impor uma nova religião, transformando-os em agentes de serviço produtivo. Vários relatos afirmavam que

\footnotetext{
32 Regimini militantis Ecclesiae: O Governo da Igreja Militante-Extraído do dicionário de latim Globe. Disponível em < https://pt.glosbe.com/la/pt/Regimini\%20militantis\%20Ecclesiae> Acesso em 11/06/2018.

${ }^{33}$ Cum ad nihil magis: Bula do Papa Paulo III que cria a Inquisição em Portugal dirigida aos bispos de Coimbra, Lamego e Ceuta pela qual os constituem seus comissários e inquisidores no reino de Portugal. ANTT, Disponível em: <https://digitarq.arquivos.pt/details?id=3908041> Acesso em 28/03/2018.
} 
eles não possuíam uma religião. Estas anotações também demonstravam a contenda que os europeus estavam tendo a respeito do universo dos selvagens e de suas condições naturais.

Entretanto diante "do código religioso", surgia um obstáculo do ponto de vista da teologia dos evangelizadores. "Os selvagens da terra de Santa Cruz não apresentavam aqueles elementos que encontramos na longa lista de d'Abbeville e que definem o que é a Religião: ídolos, templos, sacerdotes.” (POMPA, 2001). Ou seja, se não existiam estes elementos, a religião também não existia.

Por conseguinte, a partir da publicação da Bula Sublimis Deus de 1537, do papa Paulo III, concluía-se que os nativos eram homens "naturais" "(Veris homines)" e como tais eram dignos de receber a fé católica por meio da catequese e do testemunho. Era então oficializado o objetivo dos missionários:

\begin{abstract}
A necessidade, filosófica e teológica, de atribuir aos índios umas crenças, mesmo se vagas ou errôneas, obedecia a uma exigência cultural de "ler" o outro e traduzi-lo e, por outro lado, traduzir o "eu" para o outro. Para isto era necessário construir uma linguagem de mediação. No início da Idade Moderna, o código prioritário de leitura e interpretação da realidade, inclusive das alteridades antropológicas, ainda era o religioso; este último englobava todos os outros: o moral, o político, o filosófico (lembre-se a justaposição de fé, lei e rei). Ou seja, qualquer manifestação social da alteridade que a descoberta apresentava era lida sub specie religionis e traduzida na linguagem religiosa. (POMPA, 2001)
\end{abstract}

Objetivando esta cristianização no "novo mundo" português, ainda que de forma esparsa e acanhada, os primeiros a chegarem foram os Franciscanos. Contudo para atender as prerrogativas da Coroa Portuguesa, a Companhia de Jesus foi considerada a mais habilidosa, porque possuía mais cultura doutrinal, "independência, disciplina e eficiência nas missões", além de experiência em gerar receitas privadas e controle interno. (MANSO, 2016)

Sendo assim, por determinação do Rei de Portugal Dom João III, os Jesuítas chegavam ao Brasil em 1549, convencidos de uma notável "admiração pelos indígenas, desejosos não apenas de convertê-los à verdade da fé, mas também de educá-los para sua futura integração na sociedade." (AZZI, 1987). O primeiro grupo de jesuítas chegou ao Brasil na mesma expedição que trazia o Primeiro Governador Geral Tomé de Souza. Além do padre Manuel da Nóbrega, estavam os religiosos Leonardo Nunes, João de Azpilcueta Navarro, Antônio Pires, Vicente Rodrigues e Diogo Jácome.

As tentativas de colonização do novo território nas primeiras décadas do século XVI sofreram diversas revezes. Convenceu-se, então, o rei de Portugal, Dom João III, da necessidade de envolver a Monarquia na ocupação da nova terra. Institui, pois, um governo geral no Brasil, nomeando para essa função Tomé de Souza (SAVIANI, 2007, p. 25) 
Conforme ocorrera nas missões do ocidente, a Companhia de Jesus recebera grande aporte de "rendas régias e de meios econômicos para que pudesse dar andamento aos projetos missionários" (MANSO, 2016, p.158). Já no ano de 1550, os jesuítas receberam de Tomé de Souza, a Sesmaria das Águas dos Meninos, onde puderam iniciar as atividades educacionais e as agrícolas usando a mão de obra dos nativos. Nesta extensa região criaram estrutura para moldar os nativos em conformidade com os valores europeus e as normas oriundas do Concilio de Trento.

\footnotetext{
O papel dos jesuítas na colonização do Brasil e da América em geral ocupa um lugar de destaque e sem precedentes na história das missões cristãs. Ninguém ignora qual tenha sido a parte dos missionários na obra de penetração da civilização ocidental entre os povos mais primitivos. São eles que formam na vanguarda, preparando o terreno com a domesticação dos naturais (PRADO JÚNIOR, 1971, p. 24).
}

Logo a Companhia de Jesus tornava-se "a coluna dorsal do poder institucional na colônia" (MANSO, 2016, p.156). Prova disto é a elevação da Missão Jesuítica do Brasil à categoria de Província e a nomeação do padre Manuel da Nóbrega como o Provincial dos Índios do Brasil.

\section{2- Práticas jesuíticas no Brasil e a inconstância da alma selvagem}

A Companhia de Jesus precisava cumprir sua missão e converter os índios transmitindolhes a língua portuguesa, os costumes europeus e o catolicismo, com o objetivo inclusive de, cumprir a máxima profecia do Evangelho: "ide, fazei discípulos de todas as nações, batizando-os em nome do Pai, e do Filho, e do Espírito Santo".

\footnotetext{
Os padres teriam a missão de trazer os ameríndios para o mesmo estágio de evolução onde se encontravam os europeus cristianizados. O Conhecimento das escrituras e o incremento da fé removeriam os indícios de barbárie e preparariam os nativos para alcançar o reino dos céus. A conversão traria a pureza e a virtude perdidas por Adão e Eva depois de ter comido o fruto proibido. (RAMINELLI, 1996, p.31)
}

Para iniciar este trabalho missionário, os religiosos então fixaram de inicio suas moradias nas proximidades às terras indígenas. Desta maneira, como houvera inicialmente uma boa e fácil recepção, por parte dos nativos, como descrevera Nóbrega, "vistos como 
papel em branco, pronto para escrever", puderam iniciar o projeto missionário jesuítico cuja metodologia não fazia em nenhuma hipótese, menção ao lugar do outro:

\begin{abstract}
Tratava-se de trazer os indígenas, considerados como ovelhas desgarradas, para o redil da verdadeira fé. "Converter" significava basicamente tirar os índios de suas crenças errôneas e reconduzi-laos à verdade católica. Não se tratava, portanto, de um diálogo, mas de um monólogo religiosos. A teologia da conversão partia do princípio da exclusividade da fé católica, considerada como única verdadeira, e da necessidade de que todos os povos se submetessem à sua aceitação. A profissão de fé cristã tornava-se, assim, uma necessidade fundamental para se obter a salvação eterna. A proposta missionária não deixava aos indígenas alternativas: a única via possível era a conversão, condição imprescindível para a integração no projeto colonial lusitano, ou seja, na cristandade, expressão visível do projeto salvífico divino. (AZZI, 1987 p.73)
\end{abstract}

Contudo devido as constantes violências cometidas pelos colonos portugueses contra os nativos, por aconselhamento do Governador Tomé de Souza, os missionários jesuítas estabeleceram-se dentro dos limites concernentes de defesa da cidade. A partir desta nova situação era necessário então, encontrar novas práticas, novo modelo de catequização e conversão para os índios.

Os missionários da Companhia de Jesus passaram a catequizar e estruturar os nativos a partir de aldeamentos, conhecidos como reduções ${ }^{34}$. O fundamento essencial que norteava o conceito de redução era "o direito do português à nova terra, em força da doação feita pelo papa em nome de Cristo". Já para os nativos este "direito" só seria possível após a profissão da fé católica. (AZZI, 1987).

A criação dos aldeamentos ou reduções não foi ideia de Roma, mas sim das necessidades locais. A administração destes aldeamentos/reduções era realizada pelos padres, outras vezes pelos colonos e até mesmo pelos índios através de seus "chefes principais". O Estatuto das aldeias de 1558 previa apenas que os padres seriam responsáveis pela catequese, não fazendo nenhuma menção administrativa. (MANSO, 2016)

A fim de executarem uma política de fixação e evangelização do índio, criaram o aldeamento, como forma de fixar as populações habituadas ao nomadismo, evitando igualmente a prática da antropofagia e da poligamia. A aldeia/aldeamento aparece como uma adaptação às necessidades da evangelização local às terras brasílicas pensada pelos jesuítas e criada pelo governador. (MANSO, 2016 p.158)

\footnotetext{
${ }^{34}$ Reduções: Este termo é utilizado com mais frequência em territórios espanhol (reducciones)-(MANSO 2016 p.59)
} 
$\mathrm{Na}$ maioria dos casos, as comunidades indígenas distintas foram obrigadas a migrar de suas terras para esses aldeamentos, onde tinham que estudar os preceitos da Igreja e posteriormente eram batizados com nome de santos e santas católicos. Os aldeamentos eram locais onde se mantinha a estrutura comunitária dos nativos com os seus caciques, o sistema de plantio, caça e pesca misturada com a tecnologia dos europeus como "a escrita, metalurgia, olaria e a arquitetura". Eram ambientes onde os índios podiam ter liberdade para viverem em paz, mas em uma espécie de liberdade autorizada e vigiada, o que não impedia os conflitos culturais e religiosos.

A partir deste desse momento, o método de catequese missionária foi tomando um rumo diverso: não mais embrenhar-se na selva para conviver junto aos indígenas, mas, pelo contrário, trazer os indígenas para perto das povoações portuguesas, agrupando-os num espaço territorial bem delimitado. Essa tarefa de convencer o índio a abandonar o seu habitat natural para estabelecer sua residência nas proximidades do litoral, passou a ser designada como "descimento", pois em geral se fazia acompanhando o curso dos rios que "desciam" para o mar. No litoral sob a orientação dos missionários, os indígenas construíam seus aldeamentos, conhecidos com o nome de "reduções". (AZZI, 1987 p.74)

Portanto, em decorrência desta dificuldade e como uma estratégia de catequização, os padres abandonaram o latim oficial e buscaram aprender a língua nativa, empregando-a nas celebrações, músicas e nas encenações teatrais, como forma de inculturar os nativos aos rituais católicos. A língua Tupi virava a própria língua geral.

As ideias de Cristo, dos Santos, da Virgem Maria, das procissões, das vestimentas cristãs e dos "dramas bíblicos" eram assimiladas na cultura nativa através das imagens que os índios já tinham e eram apresentadas nos autos, nas peças que o Padre José de Anchieta criou. Estas peças visavam principalmente às crianças, chamadas de "curumins ${ }^{35}$ ", porque tinha o objetivo de moldar a mente cristã desde cedo. Os costumes indígenas eram ensinados como pecado e seus deuses como demônios e o Deus cristão como verdadeiro Deus.

“(...) nascia assim a língua geral, com base no tupi, veículo de tradução linguística e cultural do catolicismo para a cultura nativa. Foi com base na língua geral que se realizaram as confissões dos pecados e, mais tarde, se compuseram os próprios manuais de brasílicos." (VAINFAS/SOUZA, 2000 p.15.).

Apesar disso, os padres perceberam que o trabalho missionário seria árduo e perigoso, já que o universo religioso era percebido de modo totalmente diferente pelos indígenas. (VAINFAS; SOUZA, 1995). “A inconstância da alma selvagem” estava expressa nas palavras

${ }^{35}$ Curumim. Do tupi kunu'mi/kuru'mi. Menino de pouca idade; garoto ou rapaz. Disponível em:

$<$ https://www.dicio.com.br/curumim>. Acesso em: 10/05/2018. 
de Nóbrega ao transcrever os obstáculos para manter os ensinamentos e a conversão dos nativos:

\begin{abstract}
O converter todo este Gentio é mui fácil cousa, mas sustenta-lo em bons costumes não pode ser se não com muitos obreiros, porque em cousa nenhuma creem e estão papel branco para neles escrever a vontade, se com exemplo e continua conversação os sustentarem. (NÓBREGA, 1988 pp.124-125)
\end{abstract}

Esta dificuldade de se colocar em prática o objetivo missionário da Companhia de Jesus estava na mutabilidade do ser nativo, que estava aberto a receber a doutrina da religião dos colonizadores, mas com o passar do tempo aquele ensinamento já não mais os interessavam. Era necessário um ensinamento constante e permanente, moldando a personalidade espiritual

dos indígenas. É o que o antropólogo Eduardo Viveiros de Castro classifica em seu artigo "A inconstância da alma selvagem e outros ensaios de antropologia" como "Gente receptiva a qualquer figura, mas impossível de configurar" quando faz uma análise do "Sermão do Espírito Santo (1657) do Padre Antonio Vieira".

A tentativa destes religiosos em impor o cristianismo também evidenciava certos limites no que se refere principalmente a forma como estas práticas e tradições católicas se interiorizaram na realidade indígena. Os índios absorviam os conteúdos cristãos, fazendo uma interpretação própria desta catequese convertendo-a a sua cultura e aos seus deuses, pois eles, os tupinambá, ao contrário do que os jesuítas pensavam tinham um "sistema de crenças no qual o tema da "Terra sem Mal” ocupava um lugar maior” (H. Castres 1975).

A comunicação entre índios e estes religiosos configurava-se então como uma das maiores dificuldades criadas em detrimento das atividades catequéticas. No entanto, esta dificuldade marca de maneira significativa a realidade colonial e as relações sociais estabelecidas, explicando o caráter sincrético religioso apresentado no movimento denominado de "Santidade de Jaguaripe".

Viu-se que foi nos aldeamentos da Companhia de Jesus que padres e índios construíram a base da idolatria ameríndia. Construíram-na por meio de traduções do catolicismo para o tupi e vice-versa; por meio das circularidades entre os símbolos culturais cristãos e os indígenas (VAINFAS, 1995 p. 150).

\title{
2- Sincretismo e Matriz religiosa.
}

O antropólogo e teólogo Pierre Sanchis (1995) procura reestabelecer o Sincretismo de forma pormenorizada reelaborando-o através de um sistema ativo onde as identidades sociais 
se transformam ao entrar em contato com grupos diferentes. Estes sistemas por si só estão abertos a diversas modificações incluindo as evolutivas. Assim Sanchis vai conceituar o sincretismo como uma amalgama entre culturas e não somente de crenças, como se define na maioria das vezes, pois a religião já está incluída neste complexo como componente fundamental. Entretanto quando ocorre esta amalgama, o processo é conflituoso e sem harmonia. Haverá sempre uma cultura em desigualdade, ou seja, uma que domina e outra que é dominada. De acordo com a ocasião, o ambiente, o sujeito e seus interesses, o sincretismo estará sempre se modificando.

Este conjunto de características próprias do sincretismo está presente na formação da Matriz religiosa brasileira, pois: "o Brasil que, nascendo católico, participa desta tendência ao sincretismo, mas de modo peculiar" (SANCHIS, 1997, p.105). Sanchis para descrever e percorrer o mapa do "campo religioso contemporâneo do Brasil", propõe em sua metodologia uma ideia entorno de três componentes que ele denomina de "vareta tríplice das três modernidades, que são a pré-modernidade, a modernidade e a pós-modernidade". E conclui que a Sociogênese deste campo religioso brasileiro surge na "pré-modernidade" no período colonial, onde acontece esta "porosidade" 36 (SANCHIS, 1997, p.104).

A "pré-modernidade" ou a "Matriz Religiosa Brasileira" conseguiu compatibilizar sistemas simbólicos doutrinariamente diversos como o catolicismo, a mitologia indígena e a crença africana, através de um intercambio experimental essencialmente ritualista destas identidades religiosas onde uma complementa a outra. Neste mesmo aspecto, o filósofo e teólogo José Bittencourt Filho (2003, p.33-81) vai definir a "Matriz Religiosa Brasileira" como uma complexa interação de ideias e símbolos religiosos que se articularam neste período de formação do Brasil colonial ultrapassando as fronteiras doutrinárias das crenças e elaborando o convívio social de camadas sociais distintas pelo menos no ponto de vista da religiosidade. A religiosidade da colônia manifesta-se pela mescla de elementos católicos, indígenas e negros que vai influenciar a vida para o bem e para o mal.

\section{1-O que é sincretismo religioso}

Podemos ver o sincretismo com o um fenômeno que faz parte de um processo mais amplo, de transformações religiosas em geral. (DROOGERS, 1981 p.143).

\footnotetext{
36 "A condição de explicá-la bem, chamaremos esta porosidade de sincretismo" (SANCHIS, 1997:112)
} 
Em termo mais compreensível Sincretismo seria "a junção ou mistura de cultos ou de doutrinas religiosas distintas, atribuindo um novo sentido aos seus elementos" $37 \ldots$. O antropólogo e teólogo Pierre Sanchis destaca mais duas características deste sincretismo. Primeiro que o processo pelo qual o sincretismo acontece é polivalente o bastante para abrigar uma pluralidade de "cristalizações" e segundo que o "outro e o próprio" se rearranjam por meio destas modificações.

\begin{abstract}
Se aproximaria primeiro do fenômeno como de um universal dos grupos humanos quando em contato com outros: a tendência a utilizar relações apreendidas no mundo do outro para ressemantizar o seu próprio universo. Ou ainda, do modo pelo qual as sociedades humanas (sociedades, subsociedades, subculturas) são levadas a entrar num processo de redefinição de sua própria identidade, quando confrontadas ao sistema simbólico de outra sociedade, seja ela de nível classificatório homólogo ao seu ou não. (SANCHIS, 1994 p. 7).
\end{abstract}

Contudo a definição de sincretismo é objeto de discussão entre sociólogos e cientistas das religiões. Segundo Droogers, o melhor caminho para compreender esta diversidade surpreendente de significação de sincretismo é através de modelos específicos.

\begin{abstract}
Sincretismo é um daqueles conceitos que pairam sobre a tênue linha separando noções que nos ajudam a entender e a manter um diálogo acadêmico sobre fenômenos similares e outras que, por seu uso abusivo e repetitivo, se tornam quase completamente vazias de um real significado - dando espaço, como argumenta Trajano Filho (1990, p. 2), ao falar de um desses conceitos superestimados, a uma teorização vazia, não crítica, inconsciente de seus limites e desconectada do mundo factual. Comumente atribuído a vários e distintos fenômenos religiosos, "sincretismo" parece ter perdido, parcialmente, ao menos, sua força como uma noção capaz de capturar os aspectos criativos de contextos religiosos. Isso acontece, pode-se dizer, porque muitas vezes nos rendemos à palavra "sincretismo" ao mesmo tempo em que ignoramos as particularidades e a não homogeneidade dos distintos contextos reconhecidos debaixo desse abrangente conceito. (CASTRO, 2014, p.59)
\end{abstract}

É neste cenário de "particularidades" e ao mesmo tempo de "pluralidade", que buscamos direcionar um olhar mais centrado no protagonismo indígena através dos aspectos religiosos apresentados na Santidade de Jaguaripe, que "capturava os aspectos criativos de contextos religiosos" no encontro com o outro, neste caso especifico com os jesuítas.

O método catequético utilizado pelos jesuítas apresentava um resultado não planejado onde os índios absorviam os conteúdos cristãos, fazendo uma interpretação própria desta catequese convertendo-a a sua cultura e aos seus deuses produzindo então uma primeira ideia do que chamamos de "Sincretismo". Da mesma forma algumas práticas indígenas também

\footnotetext{
${ }^{37}$ Sincretismo: Extraído do Dicio - Dicionário Online de Português Disponível em:

$<$ https://www.dicio.com.br/sincretismo >. Acesso em: 10/05/2018
} 
foram incorporadas pelos colonizadores, onde as identidades estavam sempre abertas e se complementavam.

É assim que costumava pregar nas aldeias o padre Azpilcueta Navarro, grande "língua": "levantando a voz e pregando-lhes os mistérios da fé, andando em roda deles, batendo o pé, espalmando as mãos, fazendo as mesmas pausas, quebras e espantos costumados entre seus pregadores, para mais os agradar e persuadir.(POMPA,2006 p.124)

Um destes exemplos fora relatado através de carta epigrafada em 1552, por estudantes do Colégio da Bahia, ao padre Pero Domenech, reitor do Colégio de Lisboa. A missiva narrava às experiências dos membros da Companhia de Jesus que empregavam princípios e conteúdos indígenas para atribuir aos ensinamentos da doutrina católica. Outro método utilizado pelos jesuítas para manter a aproximação e obter a confiabilidade dos indígenas, era repetir a mesma forma que os xamãs utilizavam em seus rituais, ou seja, gritavam, balançavam o corpo e a cabeça. Esta assimilação concretiza este sincretismo religioso. (VIVEIROS DE CASTRO 2002).

O sincretismo pode ser visto com o aquela parte do processo de transformação de símbolos religiosos em que a inspiração para esta mudança vem de fora, quer de outra religião ou de outras religiões, quer da estrutura social ou da sociedade secular. Trata-se não só da mistura de ideias ou práticas religiosas, mas da atividade do homem que brinca com os símbolos da sua própria religião e com os de outras religiões (DROOGERS, 1981).

Nesta perspectiva de assimilação e transformação Sanchis acredita que o Brasil tenha sido sempre um país de pluralidade religiosa e define "o catolicismo como estrutura virtualmente sincrética". Por conseguinte como o Brasil foi colonizado pelos europeus portugueses católicos, ele já nasceu também sincrético. Contudo diferente da Europa, onde existia "um sincretismo secreto" que produzia uma identidade "consciente e unificadamente católica", aqui no novo mundo se constituía num universo "aberto e sem fim" uma união dos "diferentes": europeus católicos, indígenas e africanos. Contudo "uma união de diferentes" com estrutura totalmente desigual.

\subsection{A matriz religiosa brasileira e seu aspecto sincrético}

De acordo com a psicóloga e doutora em antropologia Maristela Andrade (2002), “o brasileiro é marcadamente religioso". Isto o faz reproduzir em sua vida um conhecimento prático de diversas configurações de crenças, de maneira que seus atos religiosos passam a 
fazer parte do "ethos da cultura brasileira". Para compreender este processo é necessário encontrar as origens do sentimento religioso brasileiro no decurso da formação da "matriz religiosa brasileira".

$\mathrm{Na}$ chegada dos portugueses ao Brasil, no século XVI, a "Dimensão mítico-religiosa" estava alicerçada em princípios existentes no imaginário "edênico", que se assemelhavam as terras do novo mundo ao paraíso. Consequentemente, para os colonizadores era necessário preservar a doutrina "salvacionista milenarista" no pensamento do brasileiro, o que resultou numa disputa hostil, fazendo com que os nativos se rebelassem ao sistema imposto pelos europeus. Os indígenas tupinambá buscavam então o paraíso terrestre, ou terra sem males, numa mistura de "noções bíblicas" do jardim do Éden com as ideias pagãs, onde sagrado e profano constituíam esta fusão.

Esta concepção "salvacionista milenarista" foi relatada nas cartas de 1549, epigrafadas pelos padres Manuel de Nóbrega e José de Anchieta, com riquezas de informações. Sendo assim, o entrelaçamento destes princípios de religiosidade e seus ritos produziram outras formas, a qual se pode conceituar de Sincretismo (ANDRADE, 2002)

\begin{abstract}
Esta gênese do Brasil colonial mostra uma configuração marcada por uma estrutura religiosa que articulava objetos diferentes que se complementavam. Havia um substrato religioso cultural, onde a crença generalizada em forças sobrenaturais influenciava a vida da maioria da população, para o bem ou para o mal. Estas forças espirituais estavam além das instituições religiosas, pois proporcionou novos modelos religiosos e impulsionou atos de devoções. A bem da verdade deve-se considerar a Matriz Religiosa Brasileira como resultado inerente ao encontro de culturas e mundividências. Pode-se dizer, em grandes linhas, que no Brasil colonial colidiram duas grandes concepções religiosas: uma que sacralizava o ambiente natural e as forças espirituais a ele subjacentes; outra ressaltava símbolos religiosos abstratos e transcendentais. (BITTENCOURT, 2003p. 49)
\end{abstract}

Em conformidade com este conceito, Bittencourt Filho, classifica a cultura indígena como a primeira compor, o que ele denomina de "Matriz Religiosa Brasileira". Resultante da assimilação, incorporação e imposição das práticas religiosas dos europeus, esta complexa interação de ideias e símbolos religiosos teve como resultado o sincretismo religioso. Esta "amalgama" entre a religiosidade ${ }^{38}$ dos nativos e a religião católica dos colonizadores europeus, permanece até os dias atuais caracterizando fortemente a identidade religiosa brasileira á partir deste modelo matricial.

Sanchis (1997) também acredita nesta perspectiva de assimilação e transformação e que o Brasil também tenha sido sempre um país de pluralidade religiosa e define "o catolicismo

\footnotetext{
${ }^{38}$ Bittencourt define religiosidade como a prática cotidiana religiosa ou de crenças vividas por uma pessoa ou pelos grupos. (BITTENCOURT, 2003 p.68)
} 
como estrutura virtualmente sincrética". Desta forma como o Brasil foi colonizado pelos europeus portugueses católicos, ele já nasceu também sincrético. Contudo diferente da Europa, onde existia "um sincretismo secreto" que produzia uma identidade "consciente e unificadamente católica", aqui no novo mundo se constituía num universo "aberto e sem fim" uma união dos "diferentes": europeus católicos, indígenas e africanos. Todavia "uma união de diferentes" com estrutura totalmente desigual.

\section{3- $O$ caso da Santidade de Jaguaripe}

É dentro deste contexto que os nativos, após adquirirem o conhecimento da fé católica, elaboraram métodos de resistência contra a escravidão e a imposição das práticas catequéticas, na procura do "Paraíso Tupi " ou da chamada "Terra sem males", sinônimo da eternidade sagrada onde estariam os ancestrais tupis, busca que fora interrompida com a chegada dos portugueses, refazendo assim o seu universo espiritual face às más condições que enfrentavam diante aos colonizadores.

Sob a influência dos índios denominados de "Caraíbas" iniciava-se os movimentos chamados pelos próprios jesuítas de "santidades". Esta designação acabou por gerar uma grande confusão, já que a afirmação de que os índios não possuíam religião era frequente nas narrativas de viajantes e religiosos. Maristela Andrade considera a Santidade como movimento religioso.

Na verdade, "santidade" era um termo genérico utilizado pelos jesuítas para denominar certos rituais ou festas tupis que ocorriam tempos em tempos, reunindo um número considerável de índios. Porém o movimento religioso que será objeto de exame em seguida tem características particulares e foi alvo de interpelações do Santo Ofício, tornando-se conhecido pelo nome de "Santidade de Jaguaripe". (ANDRADE, 2002, p. 65)

De acordo com o etnólogo Herbert Baldus, outra incumbência atribuída aos caraíbas ou xamãs, era a defesa das aldeias e dos seus integrantes. A execução desta tarefa caracterizava os caraíbas como um grupo social. (BALDUS, 1965). Além disso, os caraíbas eram

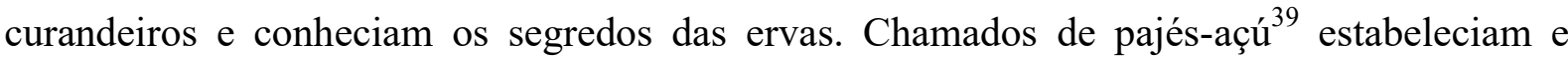
mantinham laços de relação recíproca com outras aldeias. Dispunham de grande capacidade de persuadir e convencer pela palavra e eram venerados como santos. (CRUZ, 2013). Os caraíbas foram denominados pelos padres, de acordo com as referências francesas, de "santos", "santidades" ou "profetas". Eles percorriam as aldeias pregando uma mensagem profética sobre a existência de um paraíso onde se encontrava os seus ancestrais, os heróis

39 Pajé - Açu: Grande profeta. Do Tupi Guarani Pajé = profeta. Pessoa encarregada de realizar rituais e cerimônias religiosas nas tribos indígenas. $A c ̧ u$ - adj. Bras. Radical de origem tupi, com função adjetiva, que significa grande. Extraído Dicionário Tupi-Guarani Disponível em: < https://www.dicionariotupiguarani.com.br $>$ Acesso em 12/06/2018 
indígenas e não se morria jamais. Eram recebidos com festas e muito respeito, não só pelos nativos, mais também por alguns colonizadores. Realizavam exorcismos, imitando os padres jesuítas, que por determinação de Nóbrega, somente podiam realizar a conversão depois de ensinar o catecismo e empreender o exorcismo.

\begin{abstract}
Pregavam em transe, após sorverem a fumaça de certas ervas, e de conversar baixinho com suas cabaças mágicas, todas enfeitadas de penas, pintadas com olhos, nariz e boca, pois eram elas afinal que alojavam o espírito dos deuses (...). Usam de alguns feitiços, e feiticeiros, não porque creiam neles, nem os adorem, mas somente se dão a chupar em suas enfermidades, parecendo-lhes que receberão saúde, mas não por parecer que há neles divindades, e mais o fazem por receber saúde que por algum respeito. Entre eles se alevantam algumas vezes alguns feiticeiros, a que chamam Caraíba, Santo ou Santidade, e é de ordinário alguns índios de ruim vida; este faz algumas feitiçarias, e cousas estranhas à natureza, como mostrar que ressuscita a algum vivo que se faz morto, e com esta e outras cousas semelhantes traz após si todo o sertão, enganando-os. (VAINFAS, 1995, p.13)
\end{abstract}

\title{
3.1-Descrição da Santidade
}

O movimento religioso de "caráter messiânico" denominado de Santidade de Jaguaripe recebeu esta nomenclatura, após se deslocar de Palmeiras Comprido, para as margens do Rio Jaguaripe. Jaguaripe era uma Vila instituída na época do Governador Geral Mem de Sá-1558 a 1572, onde habitavam os colonos portugueses com seus engenhos de açúcar, os nativos tupinambá e os padres jesuítas com seus aldeamentos. A região ficava ao sul do Recôncavo Baiano, às margens do Rio Jaguaripe, que quer dizer "rio da onça". Por volta de 1560 às margens do Rio Jaguaripe foi erigido um aldeamento denominado Santo Antônio para redução dos índios tupinambá e que tinha como ordenador o jesuíta Gaspar Loureço. (NUNES 2000). Por volta de 1580 o movimento iniciava a mais significativa revolta ameríndia do período Colonial, tendo como objetivo constituir um "novo paraíso" ou na linguagem tupi uma "terra sem males". (RAMINELLI 1986).

A santidade constituiu assim uma "nova religião", pois usava simbologias cristãs em certas ocasiões ao mesmo tempo em que utilizava os seus próprios conteúdos. O movimento então foi condenado e considerado pelos jesuítas como demoníaco e falso (POMPA, 2004).

Em que frequentemente a santidade é apenas a falsa aparência da natureza demoníaca. Assim, os missionários trouxeram para a América os dilemas religiosos de uma época em que a necessidade de separar o santo do diabólico era a verdadeira obsessão de inquisidores e teólogos. Este contexto foi rapidamente projetado nos discursos sobre os índios, e neste contexto, tem que ser enquadrado o uso do termo "santidade" para indicar as "cerimônias diabólicas" dos caraíbas. (POMPA, 2001, p. 188) 
A santidade de Jaguaripe inicialmente era liderada pelo índio tupinambá batizado como Antônio, que tinha as qualidades específicas de um caraíba. Teria ele fugido de seu aldeamento e a partir daí muitos seguidores não só indígenas, mas pertencentes a outros segmentos como nativos recém-convertidos e batizados que haviam vivido com os jesuítas, além de colonos portugueses, velhos e novos cristãos, mamelucos, escravos negros vindos da Guiné e brancos pobres e também possuidores de terra aderiam ao movimento, dando um caráter heterogêneo a esta Santidade. O índio Antônio conhecia os rudimentos da fé católica e a mitologia heroica tupinambá. Ele foi um ex-sacristão indígena, que não virou jesuíta e que havia assimilado todos os conteúdos cristãos articulando-os às ideias indígenas, fato que reforça o cunho sincrético do movimento. Enquanto líder da "Santidade de Jaguaripe" empregava um discurso milenarista em que se autodenominava "Tamanduare ${ }^{40}$ ", que na mitologia indígena era um dos mais importantes ancestrais do povo tupinambá.

Antônio se declarava o herói indígena e sobrevivente do segundo dilúvio, simultaneamente, dizia ser também o Papa, nomeando outros índios como bispos. Batizava utilizando água e os santos óleos. Fazia ainda o uso de alguns objetos e rituais sagrados do cristianismo como a oração do rosário e adoração as cruzes e também de objetos indígenas como os maracás e o culto ao ídolo de pedra denominado "Tupanasu"41 que se localizava no centro da igreja construída nas terras de Fernão Cabral.

Além de atribuir nomes de santos aos demais integrantes do movimento, como São Paulo, São Luiz entre outros, Antônio teria designado o nome de Santa Maria Mãe de Deus a própria mulher, e assim o clero que constituía a "Santidade de Jaguaripe" configurava-se como uma verdadeira corte celeste católica. As celebrações realizadas pelo líder caraíba misturavam:

\footnotetext{
"Cerimônias de batismo com fumaça de tabaco e os santos óleos; bailes tribais e orações com rosários feitos de sementes de frutas; confissões eram realizadas em cadeiras de um pau só com sucções de fumo em longos caniços, num transe coletivo a um só tempo cristão e indígena. Tudo presidido, nos derradeiros momentos da seita, pela índia chamada "Mãe de Deus", a Virgem tupinambá, a qual codemandava as danças e fumaças em torno de um ídolo de pedra, adornado com nariz, boca e
}

\footnotetext{
${ }^{40}$ Tamanduare: variante de Tamendonare, um dos gêmeos que sobreviveram à grande inundação, e um dos principais ancestrais daquela nação (Vainfas, 1992).

${ }^{41}$ Tupanasu: deus grande derivava de tupã, uma das formulas usadas pelos jesuítas para aludir ao deus cristão na língua tupi, a língua que serviu à catequese-(Vainfas 1995).Tupã : Progenitor. Figura da mitologia Tupi-Guarani. Ele é o mensageiro de Nhanderu (Deus) que se manifesta na forma do som do trovão. Extraído do Dicionário Tupi Guarani Disponível em: $<\mathrm{https}: / / \mathrm{www}$.dicionariotupiguarani.com.br/dicionario/tupa-3/> Acesso em $25 / 05 / 2018$
} 
cabelos, á semelhança dos maracás.ídolo chamado Tupanasu ${ }^{42}$, o grande Deus.; (VAINFAS; SOUZA, 2000, pp.19-20).

Seriam estes rituais uma maneira de resistência ao batismo cristão imposto pelos jesuítas ou de afirmação da prática católica? A perspectiva do batismo como resistência ao catolicismo figura-se como a explicação mais adequada, dado que os índios acreditavam que este conduzia a morte, e o rebatismo pela santidade significaria a vida eterna. (VAINFAS, 1995).

\footnotetext{
Elementos mais genuinamente indígenas, nós encontramos na virtude do caraíba de falar com os espíritos, na separação entre homens, mulheres e crianças, durante os cortejos que seguiam o líder, nos bailes, no uso da erva-santa, nas possessões, nos cantos e nas defumações. Sobre esses componentes não há equívoco quanto a sua origem nativa (SILVA, 1995 p.65).
}

O movimento encontra na figura controversa do senhor de engenho Fernão Cabral de Taíde, um grande apoio e proteção. Fidalgo nascido no sul de Portugal, e segundo alguns estudiosos, detentor de uma relação de parentesco direta com Pedro Álvares Cabral. Taíde abriga em suas terras o movimento, permitindo até mesmo a construção de uma igreja pelos próprios índios. (VAINFAS, 1995). O Governador Geral Manuel Teles Barreto após uma grande pressão dos colonos, dos senhores de engenho e dos Jesuítas, que ficaram muito apreensivos devido ao crescimento do movimento, determina uma primeira expedição sob o comando de Álvaro Rodrigues, com a finalidade de combater o movimento da Santidade.

Porém, persuadido pelo Senhor de Engenho Fernão Cabral de Ataíde para trocar de estratégia no combate, o Governador nomeia o próprio Cabral para combater o movimento. Todavia, Cabral passa a proteger a Santidade, o que atrai a ira do Governador que nomeia Bernaldim Ribeiro, para derrotar de vez a Santidade. Em 1585, a expedição obtém êxito e não encontra nenhuma reação por parte dos índios e tão pouco por Fernão Cabral. Segundo Vainfas (1995), o ídolo e objetos de culto construídos confiscados, a igreja construída foi incendiada, os índios foram novamente escravizados e devolvidos aos antigos senhores ou aos jesuítas, sendo seus principais líderes aprisionados, com exceção de Antônio, que desaparecera sem deixar rastro.

Sendo assim, tanto os índios como o senhor de engenho tiveram seus sonhos destruídos com o fim do movimento. Os índios não tinham mais um lugar onde poderiam viver com 
tranquilidade, em busca da "terra sem males" longe da dominação colonial, e Fernão Cabral por sua vez, não tinha mais uma grande quantidade de pessoas que posteriormente poderia trabalhar em suas terras, aumentando sua influência e poder. Enfim, os índios perderam o sonho de não serem dominados e Fernão de dominar (RAMOS; MORAIS, 2010).

\subsection{A questão do sincretismo na Santidade}

Citada nas cartas jesuíticas e fontes do século XVI, a "Santidade de Jaguaripe" é reconhecida também nos registros públicos da Coroa Portuguesa particularmente no Tribunal do Santo Ofício onde se encontram a maior parte das informações acerca deste movimento, através das inúmeras missivas de acusação e das dezenas de processos instaurados pela inquisição portuguesa.

Mesmo possuindo grande notoriedade naquele período, o movimento e suas singularidades são mais estudados pelos antropólogos e etnólogos e pouco referenciado pelos historiadores e cientistas das religiões. Procuramos perceber este movimento de Jaguaripe como uma expressão sincrética, pois ele assimila o sistema de crenças de outro, como por exemplo, os santos católicos, associando-os aos seus deuses, evidenciando assim um impressionante sincretismo religioso que segundo as fontes não era comum em outras Santidades da época.

\footnotetext{
Alguns movimentos têm tido um caráter sincrético; outros, apesar de certos préstimos do catolicismo, expressavam crenças e valores puramente indígenas. (...) Em uma tipologia do messianismo sul-americano, tais movimentos [dos messias Tukano, de 1880] se aparentam com os que se produziram em 1578[?] na região da Bahia entre os índios tupinambá meio cristializados, assim como na zona missioneira do Paraguai. (METRAUX, 1973, p. 15,29).
}

Para entendimento do sincretismo na Santidade de Jaguaripe é necessário compreender que o vínculo entre religião e civilização exerceu um papel decisivo no confronto entre europeus e ameríndios deste a Conquista Espiritual do Novo Mundo. Neste processo ocorreu certa "mediação" onde os europeus jesuítas eram exímios na criação destes "códigos compartilhados". (POMPA, 2006). No entanto, os nativos com participação ativa neste processo tornaram-se a outra parte desta "mediação". Como exemplo podemos citar o fato do líder da Santidade se considerar papa e assim nomear alguns índios como bispos e dar nomes 
de santos aos integrantes do movimento. Desta forma demonstrou extraordinariamente esta transformação definitiva de "códigos e registros" numa complexidade existente no âmbito da sociedade colonial, onde a convivência e assimilação cultural faziam-se profundamente presente. Esta convivência está explícita quando os padres jesuítas usavam os aspectos do homem ameríndio para pregarem fazendo uso de gestuais próprios dos rituais xamânicos.

Considerando as referências do século XVI, a antropologia descobriu que "as cosmologias indígenas" se compõem e se recompõem ao longo da história no enfrentamento com outras cosmologias, reconstituindo assim através destes elementos alheios, novos significados. Este sincretismo torna-se então um elemento presente não apenas nesta santidade, mas em toda a sociedade que se desenvolveu nos primórdios do período colonial. $\mathrm{O}$ historiador Serge Gruzinski trabalha com a perspectiva de um processo de cristianização que se deu através da religião, e embora seu recorte de pesquisa seja dedicada a colonização espanhola no México, podemos usar suas análises também para compreender como este processo se deu na colonização portuguesa no Brasil.

A denominada "realidade" colonial transcorria em um tempo e espaço distinto, e era pautada em princípios sociais e de poder, onde cada indivíduo teria sua própria percepção acerca do divino, do real e do além. Este distanciamento existente entre os sistemas de representação ou de poder estaria então diretamente vinculado à maneira com que as sociedades em questão "percebiam, memorizavam e comunicavam aquilo que concebiam como realidade, ou melhor, como a sua realidade" (GRUZINSKI, 2003).

Por conseguinte, ao empreenderem sua missão evangelizadora, os colonizadores almejavam algo que Gruzinski afirma ser simultaneamente fácil e impossível: a incorporação do sobrenatural cristão na realidade exótica dos índios. A facilidade se dava porque mesmo havendo uma distância entre estas sociedades, as duas enalteciam o aspecto surreal concebendo-o enquanto realidade essencial e indiscutível do ordenamento das coisas.

Estes aspectos também podem ser verificados no contexto colonial brasileiro, dado que, tanto os portugueses, principalmente os jesuítas, como os índios passaram a projetar sobre a "realidade" do outro seus costumes, práticas e representações culturais. Os índios passaram a interpretar este universo cristão enquanto um elemento novo e complementar a sua própria religiosidade, adotando assim, alguns rituais, objetos e personagens pertencentes e essenciais para a fé católica. Já o processo missionário europeu construiu esta "alteridade indígena” com base nos princípios de âmbitos religiosos como "a fé, a profecia e a esfera demoníaca". (POMPA, 2006). 
Destarte, esta tentativa de promover e impor uma "cristianização" a cultura e, sobretudo a religiosidade nativa ,acabaram por desencadear uma complexidade as relações sociais que se desenvolveram, condicionando a existência de uma nova cultura religiosa, sendo o sincretismo seu elemento central.

\begin{abstract}
A comunidade tupi do litoral no século XVI sob o domínio lusitano enfrentou nos primeiros passos do projeto português relativa superioridade dos armamentos bélicos, perplexidade e o medo provocado pelo desconhecido, além da prática do cerco, queima das aldeias e destruição das roças. Para, além disso, elementos novos foram sendo introduzido na esfera colonial (...). Os traumas psicológicos e as práticas de dominação sofridas por esses povos fez emergir um sentimento de perplexidade e de despossessão dado a destruição do seu mundo clássico e da sua autoimagem positiva a partir do momento em que se estabeleciam novas formas de relação hierarquizadas, para tanto, o processo serviu de guia para que os povos ameríndios buscassem novas formas de relacionamento e reorientarem novos paradigmas (JESUS, 2013 p. 4).
\end{abstract}

O sincretismo religioso constitui-se então como característica central da "Santidade de Jaguaripe", e se manifesta no discurso usado, nos elementos e objetos empregados no culto, na sua própria constituição e em seus principais personagens, o índio caraíba Antônio e o Senhor de engenho português Fernão Cabral de Taíde. Mediante ao contexto de um movimento marcado significativamente pelo sincretismo, a religião torna-se elemento crucial, visto que a dominação colonial portuguesa conta com o apoio dos missionários jesuítas para interiorizar-se, mesmo que através da violência e da imposição na realidade indígena. Assim, a emergência do movimento se dá como uma resposta a esta dominação.

\footnotetext{
Convém assinalar a propósito, que embora sua mensagem anticolonialista possuísse forte conotação étnica e social -, pois pregava a morte ou a escravização da "gente branca" -, era no domínio religioso que a rebelião afirmava sua identidade construindo-a por oposição à Igreja católica. Utilizava-se, pois, um rito católico-o batismo - para invertê-lo e neutralizá-lo. Se o batismo dos jesuítas simbolizava o ingresso dos índios na comunidade cristã, o rebatismo da santidade procurava anular aquele trânsito cultural, limpando os neófitos da nódoa mortal do sacramento cristão. (VAINFAS, 1995).
}

\title{
Conclusão
}

A análise da Santidade de Jaguaripe enquanto um fenômeno sincrético religioso deve considerar os trânsitos culturais percorridos pelos missionários e indígenas, distintos indivíduos no tempo e no espaço de um continente a outro, buscando perceber como se encontraram e como as relações se estruturaram, visto que longe das visões dualistas que 
costumam opor o Ocidente aos outros, colonizadores e índios, vencidos e vencedores, as fontes nos revelam paisagens misturadas muitas vezes surpreendentes e sempre imprevisíveis.

Desde os primeiros contatos entre missionários portugueses e indígenas esta relação entre religião e cultura ocorre como uma dimensão de transito simbólico que teve o "religioso como linguagem de mediação" compreensível entre as duas vertentes. Merece destaque como um dos resultados desta mediação, o modelo de catequização utilizado pelos jesuítas através do teatro criado por José de Anchieta na própria língua dos nativos. Este novo modelo catequético intencional, ao mesclar a doutrina católica com a mitologia tupinambá, cria um terceiro elemento simbólico onde, por exemplo, o bispo é denominado como Paíguaçu, o Pajé maior e Nossa Senhora é Tupanasy, a mãe de Tupã. (POMPA, 2006)

O catolicismo europeu, aqui considerado como o "eu" elaborava a "alteridade indígena" através dos âmbitos da fé, da profecia e do universo demoníaco. Por conseguinte construía o seu projeto missionário tendo com objeto a pregação do evangelho a todos os cantos e como meta principal a evangelização dos nativos. Ao mesmo tempo o "outro", que é o indígena, projetava uma interpretação própria da "alteridade" dos colonizadores, assimilando por meio de recursos próprios a crença e os rituais.

Gruzinsky (2001) considera a Monarquia católica enquanto uma zona interativa na qual se reproduziram relações entre os poderes, culturas e segmentos sociais, ocasionando incompreensões e conflitos que escaparam as estratégias de expansão. Assim sendo, a Santidade de Jaguaripe confirma esta perspectiva, ao mostrar que as limitações da imposição da religiosidade católica resultaram na adoção do que Ronaldo Vainfas (1995) chama de "catolicismo a moda indígena". Diferentemente de outras santidades, a de Jaguaripe apresentava este aspecto sincrético religioso, mesmo enquanto um movimento de resistência.

Através das fontes estudadas percebemos a incorporação do índio no processo da formação religiosa do Brasil através das relações que se estabeleceram a partir da chegada dos portugueses. Neste seguimento, uma interpretação feita pela socióloga Isabelle Braz Peixoto da Silva em "A Santidade de Jaguaripe: Catolicismo popular ou religião indígena? (1995)" explora uma concepção do movimento ligada a religiosidade. Semelhante a Silva, salientamos que o movimento bem como o contexto regional da Bahia naquela época expressava aspectos de uma sociedade complexa marcada pelo sincretismo e pela fluidez das fronteiras religiosas.

Mesmo com o fim do movimento,em 1595, referenciado pelos historiadores como uma derrota, cremos que os resultados oriundos da Santidade de Jaguaripe e que ajudaram a compor a "Matriz Religiosa Brasileira", comprovaram o contrário, visto que configuraram evidências de que os nativos mesmo em circunstâncias de dominação demonstraram 
habilidade de adaptar discursos e comportamentos capazes de preservar sua identidade através do aparato religioso. A Santidade de Jaguaripe dava existência a um novo sistema de crença conciliador e com aspectos múltiplos, o que atraia diversos seguidores como mamelucos, escravos fugidos, colonos, brancos europeus pobres e ricos, bem como índios de diversas santidades (POMPA 2004). Esta relação entre missionários católicos e indígenas acontecia pela similaridade entre os princípios da espiritualidade tupinambá e cristã: a busca por uma terra sem males, sinônimo da eternidade sagrada onde estariam os ancestrais tupis e pelo imaginário "edênico" que assemelhava as novas terras ao paraíso bíblico.

Essa fusão caracterizou segundo as fontes, a base religiosa vivida na Santidade de Jaguaripe: o sincretismo como manifestação integrante de um "processo mais amplo de transformações religiosa em geral" (DROGGERS1981).

\section{Referências}

ABREU, Capistrano de. Capítulos de história colonial (1500-1800): os caminhos antigos e o povoamento do Brasil. $5^{\text {a }}$ edição. Rio de Janeiro: Sociedade Capistrano de Abreu, 1969. ANDRADE, Maristela Oliveira de. 500 anos de catolicismos e sincretismos no Brasil. João Pessoa. Editora Universitária, 2002.

AZZI, Riolando. A Cristandade Colonial: Mito e Ideologia. Petrópolis, RJ: Editora Vozes, 1987

BALDUS, Herbert. O xamanismo. Revista do Museu Paulista. N. S. vol. 16, São Paulo. 1965/66.

BITTENCOURT, F.J. Matriz religiosa brasileira: Religiosidade e mudança social. Petrópolis, RJ: Vozes. 2003.

CALASANS, José. Fernão Cabral de Ataíde e a Santidade de Jaguaripe. Salvador: EDUFBA, 2013.

CASTRO, Josué Tomasini. Sincretismo como cruzar de memórias em contextos africanos: em defesa da precisão in: Ciências da Religião: história e sociedade, São Paulo, v. 12, n. 1, p. 56-80, jun. 2014.

CLASTRES, Hélène. La Terre sans Mal: le prophétisme tupi-guarani. Paris: Seuil. 1975. CONSTITUIÇÕES da Companhia de Jesus: normas complementares. São Paulo: Editora Loyola. 2004.

COSTA, Célio Juvenal. A racionalidade jesuítica em tempos de arredondamento do mundo: o Império Português (1540-1599). Tese de Doutoramento. Piracicaba: Unimep, 2004. CRUZ, Carlos Henrique A. Inquéritos nativos: os pajés frente à Inquisição. Dissertação (Mestrado) - Universidade Federal Fluminense, Instituto de Ciências Humanas e Filosofia, Departamento de História, 2013, p.66.

DROOGERS, André. "Sincretismo." Estudos Teológicos 21.3 (1981): 139-150. Disponível em: $\leq h t t p: / / p e r i o d i c o s . e s t . e d u . b r / i n d e x . p h p / e s t u d o s \_t e o l o g i c o s / a r t i c l e / v i e w / 1335>$ Acesso em: 26. Ago. 2016.

ECHANÍZ, Ignácio. Paixão e glória: História da Companhia de Jesus em corpo e alma. São Paulo: Loyola, 2006. 4 tomos

ELIADE, Mircea. El chamanismo y Ias técnicas arcaicas dei extasis. México. Ed. Fondo de Cultura Econômica. 1960. 
FERRETTI, Sérgio Figueiredo. Repensando o sincretismo: estudo sobre a casa de minas. São Paulo: Editora da Universidade de São Paulo; São Luís: FAPEMA, 1995.

FILHO, José Bittencourt. Matriz Religiosa Brasileira: Religiosidade e Mudança Social. Petrópolis, RJ, Editora Vozes: 2003.

GRUZINSKI, Serge. A Cristianização do Imaginário. In: A Colonização do Imaginário: sociedades indígenas e ocidentalização no México espanhol. Séculos: XVI- XVIII. São Paulo: Companhia das Letras, 2003, p. 271-294.

Os mundos misturados das monarquias católicas e outras connected

historiem. Topoi, Rio de Janeiro, 2001, pp. 175-195.

JESUS, Edvaldo Nascimento de. Antagonismo Colonial: A santidade de Jaguaripe e a Construção da liberdade no século XVI no recôncavo baiano. In: II Simpósio Internacional de Estudos Inquisitoriais: 2013 UFRB. Salvador. Disponível em: $<$ http://www3.ufrb.edu.br/simposioinquisicao/wp-content/uploads/2014/02/2013-

Texto_Edvaldo_Nascimento.pdf. >Acesso em: 23/08/2016.

LARROYO, Francisco. História Geral da Pedagogia. São Paulo: Mestre Jou, 1982. t 1.

MANSO, M. D. B. História da Companhia de Jesus em Portugal. Lisboa Ed. Parsifal. 2016.

METRAUX, Alfred. "Messias índios", in Religion y magias indigenas de América del sur. Espanha, Aguilar, 1973.

MIRANDA, Mário França. Inculturação da fé e sincretismo religioso. In: Inculturação da fé: uma abordagem teológica. São Paulo: Loyola, 2001.

MONTERO, Paula (org.). Deus na Aldeia: missionários, índios e mediação cultural. São Paulo, Globo, 2006.

NÓBREGA, Manuel da. Cartas do Brasil 1549-1560.Rio de Janeiro, Publicações da Academia Brasileira de Letras, 1931. (Biblioteca de Cultura Nacional, História - II. Cartas Jesuíticas - 1.)

NUNES, Antonieta d'Aguiar. "Centenário de elevação da primeira vila do Recôncavo baiano (Jaguaripe) a cidade." In: Revista do Instituto Geográfico e Histórico da Bahia, Salvador, v. 95, 2000, pp. 153-196.

POMPA, Cristina 2006. "Para uma antropologia histórica das missões". In: P. Montero (org.). Deus na aldeia. Missionários, índios e mediação cultural.

"Profetas e santidades selvagens: missionários e caraíbas no Brasil

Colonial”. In: Revista Brasileira de História. São Paulo, v. 21, nº 40, 2001, p. 188-189.

O profetismo tupi-guarani: a construção de um objeto antropológico. In

Revista de Índias. São Paulo, CEBRAP, vol. LXIV nº 230,2004 P.141-174,

PRADO JÚNIOR, Caio. Evolução Política do Brasil e outros estudos. 7. Ed. São Paulo:

Brasiliense, 1971.

RAMINELLI, Ronald. Imagens da colonização:a representação do índio deCaminha a Vieir a. Rio de Janeiro:Jorge Zahar Ed., 1996.

RAMOS, Fábio Pestana; MORAIS, Marcus Vinícius. Eles formaram o Brasil. São Paulo: Contexto, 2010.

RODRIGUES, Francisco. História da Companhia de Jesus na Assistência de Portugal. Tomo I, volume 1. Porto: Apostolado da Imprensa, 1931a.

SANCHIS, Pierre. As tramas Sincréticas da História: sincretismo e modernidades no espaço luso brasileiro, Revista Brasileira de Ciências Sociais, n. 28, São Paulo, pp. 123-138, junho. 1995.

“O Campo Religioso no Brasil”. In: Ari Pedro Oro, STEIL, Carlos

Alberto. Globalização e religião. 1997. Petrópolis: Vozes, pp.103-117.

. Pra não dizer que não falei de sincretismo. In: Comunicações do ISER, Rio de Janeiro, n. 45, p. 5-11, 1994. 
SAVIANI, Dermeval. A História das ideias pedagógicas no Brasil. Campinas: Autores Associados, 2007.

SILVA, Isabelle Braz Peixoto do. A santidade de Jaguaripe. Revista de Ciências Sociais, $\mathrm{n}^{\mathbf{0}}$ : 1-2, v.26, p. 65-70. 1995.

VAINFAS, Ronaldo. A heresia dos índios: catolicismo e rebeldia no Brasil Colonial. São Paulo: Companhia das Letras, 1995.

, Ronaldo. SOUZA, Juliana Beatriz de. Brasil de todos os Santos. $1^{\text {a }}$ edição. Rio de Janeiro: Jorge Zahar, 2000.

VIEIRA, Antônio Sermão do Espírito Santo (1657). Apud. CASTRO, Eduardo Viveiros de. A Inconstância da Alma Selvagem e Outros Ensaios de Antropologia. São Paulo: Cosac \& Naify, 2002, pp. 183-184.

SILVA, Isabelle Braz Peixoto da. A santidade de Jaguaripe:Catolicismo ou Religião popular Revista de Ciências Sociais v.26 n.1/2 1995. pp. 65- 70

SILVA, Willian Dias da. MAIA, Letícia D. "Resistência e Sincretismo Religioso: A Santidade de Jaguaripe no Tribunal Inquisitorial". In: Anais da XXXII Semana de História da Universidade Federal de Juiz de Fora. "O papel social do historiador: desafios contemporâneos para a escrita da História”, Juiz de Fora, 2017, p.1209-1223 Disponível em: $<$ http://www.ufjf.br/semanadehistoria/files/2010/02/Anais-UFJF1.pdf $>$ Acesso em: 23/03/2018.

VIVEIROS DE CASTRO, Eduardo B.. A Inconstância da Alma Selvagem e Outros Ensaios de Antropologia. São Paulo: Cosac \& Naify. 552 pp. 2002. 